\title{
Sediment residence time reveals Holocene shift from climatic to vegetation control on catchment erosion in the Balkans
}

Alexander Francke ${ }^{1,2}$, Anthony Dosseto ${ }^{1,2}$, Konstantinos Panagiotopoulos ${ }^{3}$, Niklas Leicher ${ }^{3}$ Jack $^{3}$ H. Lacey ${ }^{4}$, Styliani Kyrikou ${ }^{3,5}$, Bernd Wagner ${ }^{3}$, Giovanni Zanchetta ${ }^{6}$, Katerina Kouli ${ }^{5}$, and Melanie J. Leng ${ }^{4,7}$

${ }^{1}$ Wollongong Isotope Geochronology Laboratory, School of Earth, Atmospheric and Life Sciences, University of Wollongong, Wollongong, NSW 2522, Australia

${ }^{2}$ GeoQuEST Research Centre, School of Earth, Atmospheric and Life Sciences, University of Wollongong, Wollongong, NSW 2522, Australia

${ }^{3}$ Institute of Geology and Mineralogy, University of Cologne, Cologne, 50674, Germany

${ }^{4}$ NERC Stable Isotope Facility, British Geological Survey, Nottingham, NG12 5GG, UK

${ }^{5}$ Department of Geology and Geoenvironment, National and Kapodistrian University of Athens, Athens, 15784, Greece

${ }^{6}$ Deparment of Earth Sciences, University of Pisa, Pisa, 56126, Italy

${ }^{7}$ Centre for Environmental Geochemistry, School of Biosciences, Sutton Bonington Campus, University of Nottingham, Loughborough, LE12 5RD, UK.

Correspondence to: Alexander Francke (afrancke@uow.edu.au)

Keywords: soil systems evolution, geomorphology, landscape evolution, human impact, Balkan Peninsula, Uranium is otopes, sediment residence time, paleoclimate, Lake Ohrid, tephrochronology 


\section{Abstract}

Understanding the evolution of soil systems on geological time scales has become fundamentally important to predict future landscape development in light of rapid global warming and intensifying anthropogenic impact. Here, we use an innovative uraniu $m$ isotope-based technique combined with organic carbon isotopes and elemental ratios of sediments from Lake Ohrid (Macedonia/Albania) to reconstruct soil system evolution in the lake's catchment during the last $\sim 16,000$ cal yr BP. Uranium isotopes are used to estimated the paleo-sediment residence time, defined as the time elapsed between formation of silt- and clay sized detrital matter and final deposition. The chronology is based on new cryptotephra layers identified in the sediment sequence. The isotope and elemental data are compared to sedimentary properties and pollen from the same sample material to provide a better understanding of past catchment erosion and landscape evolution in the light of climate forcing, vegetation development, and anthropogenic land use.

During the Late Glacial and the Early Holocene, when wide parts of the catchment were covered by open vegetation, wetter climates promoted the mobilisation of detrital matter with a short paleo-sediment residence time. This is explained by erosion from deeper parts of the weathering horizon from thin soils. Detrital matter with a longer paleosediment residence time, illustrating shallow erosion of thicker soils is deposited in drier climates. The coupling between climatic variations and soil erosion terminates at the Early to Mid-Holocene transition as evidenced by a pronounced shift in uranium isotope ratios indicating that catchment erosion is dominated by shallow erosion of thick soils only. This shift suggests a threshold is crossed in hillslope erosion, possibly as a result of a major change in vegetation cover preventing deep erosion of thin soils at higher elevation. The threshold in catch ment erosion is not mirrored by soil development over time, which gradually increases in response to Late Glacial to Holocene warming until human land use during the Late Holocene promotes reduced soil development and soil degradation. Overall, we observe that soil system evolution is progressively controlled by climatic, vegetation, and eventually by human land use over the last $\sim 16,000$ years.

\section{Introduction}

Soil systems and their development over time play a substantial role in controlling atmospheric greenhouse gas concentrations (e.g. Broecker, 1998; Gaillardet et al., 1999). At the same time, soil development and landscape evolution are strongly dependent on climate forcing and vegetation development if tectonic uplift is negligible (e.g. Kosmas et al., 1997; Marston, 2010; Cogez et al., 2015). Up to 65\% of the world's ice-free landscapes are projected to experience significant modification over the $21^{\text {st }}$ century due to erosional processes caused by rapid climate change, which increases to $80 \%$ when the impact of human land use is considered (Ostberg et al., 2018). However, it remains to be determined whether climate change or human land use will be the primary driver of soil degradation in the near future (Ostberg et al., 2018), in part because our understanding of soil development and catchment erosion on geological time scales is poor (Marston, 2010). It is therefore crucial to improve our understanding of how natural landscapes evolve at the millennial scale.

Highly-resolved paleoenvironmental archives, from which paleoclimate information, the landscape's response, and soil system evolution can be reconstructed from the same sample material, are needed to understand the long-term behaviour of soil systems. These requirements can be fulfilled by lacustrine deposits, which can provide highresolution archives sensitive to local and regional paleoenviron mental change (e.g. Cohen, 2003). However, there are very few analytical techniques that enable quantitative estimates of past soil system evolution to be determined from lacustrine deposits. 
estimates of past catchment erosion (e.g. DePaolo et al., 2006; Lee et al., 2010; DePaolo et al., 2012; Dosseto and Schaller, 2016) as they are sensitive to changes in the depth of hillslope erosion, the spatial origin of sediments (erosion of areas with thin versus thick soil covers), and the duration of alluvial transport. Uranium-234 becomes continuously depleted from detrital matter by: (a) direct recoil of ${ }^{234} \mathrm{Th}$, an intermediate product between ${ }^{238} \mathrm{U}$ and ${ }^{234} \mathrm{U}$, (b) preferential leaching of ${ }^{234} \mathrm{U}$ embedded in the recoil tracks, and (c) preferential oxidation of ${ }^{234} \mathrm{U}$ compared to ${ }^{238} \mathrm{U}$ (Dosseto et al., 2008a; Ma et al., 2010; Suresh et al., 2013; Suresh et al., 2014a; Suresh et al., 2014b; Gontier et al., 2015). The depletion of ${ }^{234} \mathrm{U}$ becomes significant in the outer rim of detrital grains with large surface-to-volu me ratios. Consequently, $\left({ }^{234} \mathrm{U} /{ }^{238} \mathrm{U}\right)$ activity ratios are a measure for the time elapsed since physical and chemical weathering has transformed parent material to fine-grained clastic matter. In combination with gas sorption analyses to examine the surface properties of detrital matter, uranium isotopes can be used to estimate the time elapsed since a parent material was weathered to regolith, known as the weathering (Dosseto and Schaller, 2016) or comminution age (DePaolo et al., 2006; Lee et al., 2010). The sediment residence time in the catchment can then be estimated by excluding the time since deposition (Fig. 1).

Pioneering work in the application of uranium isotope analyses to infer past catchment dynamics from temporally highly-resolved lacustrine deposits has recently been carried out by Rothacker et al. (2018). The study conducted on a Late Glacial to Holocene record from Lake Dojran (Former Yugoslav Republic of Macedonia (FYROM)/Greece) revealed that rainfall promoting deep erosion in wetter conditions was the primary control on soil system evolution prior to any human perturbations, and changes in vegetation density only had a minor influence on the evolution of soil systems.

Here, we apply uranium isotope analyses to Late Glacial to Holocene sediments from Lake Ohrid (FYROM/Albania) to better understand past erosion processes and soil system evolution at millennial and sub-millennial scales in response to rainfall forcing and vegetation density changes, and, during the Late Holocene, by anthropogenic activity. For this purpose, we combine uranium isotope analyses with carbon isotope composition of bulk organic matter $\left(\delta^{13} \mathrm{C}_{\text {org }}\right)$, titanium to potassium $(\mathrm{Ti} / \mathrm{K})$ ratio, sedimentation rates, total inorganic carbon (TIC), total organic carbon (TOC), and potassium (K) intensities from the same core. This allows the inference of past soil system evolution, paleoclimate conditions, and vegetation history (pollen) from the same site. The sedimentary (sedimentation rates), (bio-) geochemical (TIC, TOC, $\delta^{13} \mathrm{C}_{\mathrm{org}}, \mathrm{K}, \mathrm{Ti} / \mathrm{K}$ ) and biological (pollen) proxy data have been published previously at lower resolution, with a particular focus on climate variability at orbital (glacial/interglacial) time scales back to $\sim 630$ ka (Francke et al., 2016; Sadori et al., 2016; Zanchetta et al., 2018) as part of the International Continental Scientific Drilling Program (ICDP) Scientific Collaboration on Past Speciation Conditions in Lake Ohrid (SCOPSCO) project. These studies provide a detailed understanding of the proxy responses. Higher-resolution studies on a millennialcentennial scale during the Late Glacial to Holocene have been conducted on other shorter lacustrine sediment cores from the Ohrid-Prespa basin (e.g. Belmecheri et al., 2009; Lézine et al., 2010; Vogel et al., 2010a; Wagner et al., 2010; Wagner et al., 2012), but not on the sediments of the DEEP site. This study presents the first continuous and undisturbed Late Glacial to Holocene sedimentary archive from the depocenter of Lake Ohrid with a chronological framework based on published and unpublished tephrostratigraphic data that are in excellent agreement with other paleoclimate records from the vicinity. Our findings highlight the efficacy of uranium isotopes as a tool to provide valuable information on catchment wide erosion processes and are in agreement with other studies from the region. The continuity of our record and the comprehensive environmental data set show for the first time on the Balkan Peninsula that a threshold shift towards significantly improved hillslope stabilisation occurred at the Early to MidHolocene transition. 
Lake Ohrid is located in a tectonic basin on the border between FYROM and Albania (Fig. 2) at an altitude of $693 \mathrm{~m}$ above sea level (asl). Adjacent mountains to the West (Galičica Mountains) and East (Mocra Mountains) reach up to 2,300 $\mathrm{m}$ asl and 1,500 $\mathrm{m}$ asl, respectively. Lake Ohrid is ca. $30 \mathrm{~km}$ long and $15 \mathrm{~km}$ wide, and covers a surface area of $55.4 \mathrm{~km}^{2}$. The maximum water depth is $293 \mathrm{~m}$ and averages at $\sim 151 \mathrm{~m}$ with a total water volu me of $50.7 \mathrm{~km}^{3}$. Lake Ohrid is drained by the Crni Drim River to the North $(60 \%)$ and water is also lost by evaporation (40\%). The lake is mainly fed by sublacustrine karst springs along the eastern shoreline (55\%), and by direct precipitation and river inflow (45\%, Matzinger et al., 2006). Major inlets, which supply most of the clastic matter to Lake Ohrid, are concentrated along the northeastern (Macedonian tributaries), southwestern, and southern (Albanian tributaries)

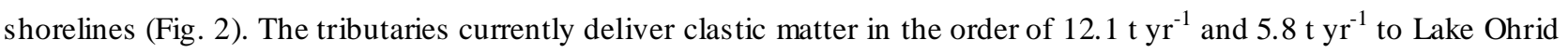
(Vogel et al., 2010b). The Sateska, which was artificially diverted towards Lake Ohrid in 1962, Koselska, and Cerava streams supply $0.6,1.0$ and $0.3 \mathrm{t} \mathrm{y}^{-1}$, respectively. A subaquatic delta system has formed in the southeastern corner of the lake and is mainly fed by the Cerava stream. Fine-grained suspended load is redistributed in the lake by counterclockwise surface currents (Vogel et al., 2010b) or contourite drift (Wagner et al., 2012). Additionally, sediment transport is also controlled by strong winds of predominately northerly and southerly directions, which cause wave action and sediment suspension along the shorelines. Lake Ohrid is oligotrophic and a complete overturn of the water column occurs irregularly every few years when winter temperatures are low, whereas the upper $150 \mathrm{~m}$ of the water column are mixed every year (summarized from Matzinger et al., 2007).

The catchment area of Lake Ohrid $\left(2,393 \mathrm{~km}^{2}\right)$ comprises Lake Prespa, which is located approximately $10 \mathrm{~km}$ to the east at an altitude of $848 \mathrm{~m}$ asl, as both lakes are connected via the karst system of the Galičica Mountains. The direct drainage area of Lake Ohrid, excluding Lake Prespa, covers a surface area of $1,002 \mathrm{~km}^{2}$. The tub-shaped morphology of the Lake Ohrid basin is due to its origin as a pull-apart basin that started to develop during the latter stages of the Alpine orogeny (Aliaj et al., 2001; Hoffmann et al., 2010; Lindhorst et al., 2015). Steep slopes form the eastern and western flanks, and more gentle slopes terminate on the northern, northeastern, and southern end of the basin. A wide flat plain stretches to the north of Lake Ohrid (Vogel et al., 2010b). Rivers and creeks in the catchment form V-shaped valleys and four glacial moraine sequences have been mapped in the Galičica Mountains between 1780 and $2050 \mathrm{~m}$ asl (Ribolini et al., 2011). The uppermost moraine sequence between an altitude of 2010 and $2050 \mathrm{~m}$ asl is dated to the Younger Dryas (Gromig et al., 2018).

Geological units in Lake Ohrid's catchment area comprise Devonian metasedimentary rocks (phyllites) in the northeastern parts of the basin, Triassic carbonates and siliciclastic rocks in the southeast, east, and northwest, and Jurassic ultramafic metamorphic and igneous rocks (ophiolites), which crop out along the eastern shoreline (Hoffmann et al., 2010). Unconsolidated lacustrine and fluvial sedimentary deposits of Quaternary age cover the plain area to the north of Lake Ohrid (Fig. 2).

Lake Ohrid is characterized by a sub-Mediterranean climate with hot and dry summers (average monthly air temperature $+26^{\circ} \mathrm{C}$ ) and cold and wet winters (average monthly air temperature $-1{ }^{\circ} \mathrm{C}$ ). The annual precipitation averages $\sim 750 \mathrm{~mm} \mathrm{yr}^{-1}$, but is significantly enhanced at higher elevations (Popovska and Stavric, 2004) as local annual rainfall within the Prespa catchment varies from $750 \mathrm{~mm}$ in the lowlands to over $1200 \mathrm{~mm}$ in the mountains (Hollis and Stevenson, 1997; Watzin et al., 2002). The majority of winter precipitation at high elevations is snowfall.

\section{Material and methods}

Sediment material investigated for this study was retrieved from the DEEP (5045-1) site in the central part of Lake Ohrid at a water depth of $243 \mathrm{~m}$ (Fig. 2B). Details about the deep drilling campaign of the ICDP SCOPSCO project can be found in Wagner et al. (2014) and Francke et al. (2016). Here, we focus on the Last Glacial to Holocene 
from the chronology of Francke et al., 2016).

Within the scope of this study we provide new, unpublished data about uranium isotope and gas sorption analyses and previously published data at a higher resolution (for sedimentary, pollen, and carbon isotope, and tephrostratigraphy). All data presented herein have not been discussed in a paleoclimate and paleoenvironmental context at a millennium and sub-millennium scale for the Late Glacial and Holocene by previous studies, which have focussed on orbital climate variability back to $\sim 630 \mathrm{ka}$. Detailed information about applied methods can be found in relevant publications as listed below and in the supplement.

Sedimentary analyses (TIC, TOC, XRF-core scanning) were carried out at the Institute of Geology and Mineralogy of the University of Cologne and increases the resolution fro $16 \mathrm{~cm}$ to $8 \mathrm{~cm}$ (for TIC and TOC) as previously published by Francke et al. (2016). XRF core scanning was conducted at $2.5 \mathrm{~mm}$ by Francke et al. (2016).

Tephrostratigraphic analyses were carried out at the Institute of Geology and Mineralogy of the University of Cologne and the Department of Earth Sciences of the University of Pisa. The analyses build on tephrostratigraphic work on Lake Ohrid's sediments by Leicher et al. (2016) and identified three new cryptotephra horizons within the DEEP site sequence.

Palynological analysis was performed at the National and Kapodistrian University of Athens (Greece) and the Institute of Geology and Mineralogy at the University of Cologne (Germany) on 45 weighed samples taken every $16 \mathrm{~cm}$. This increases the temporal resolution of the published skeleton pollen record from the Lake Ohrid DEEP core (approximately 1900 years and $64 \mathrm{~cm}$ sampling intervals; Sadori et al. 2016) in order to discern rapid climate oscillations that occurred over the last $17 \mathrm{ka}$, as well as natural and/or anthropogenic changes in the vegetation at centennial temporal resolution.

Carbon isotope analyses were carried out at $16 \mathrm{~cm}$ resolution at the British Geological Survey (UK, Lacey et al., 2015) and increases the sample resolution from $64 \mathrm{~cm}$ as published by Zanchetta et al. (2018) to $16 \mathrm{~cm}$.

Uraniu m isotope analyses (16 cm resolution) and gas sorption (64 cm resolution) analyses have not been previously applied to sediments of Lake Ohrid and were carried out in the Wollongong Isotope Geochronology Laboratory (WIGL), University of Wollongong (Australia). Sample treatment, multi-collector ICP-MS and gas sorption analyses follow the laboratory methods of Francke et al. (2018).

Paleo-sediment residence times were modelled using uranium isotopes and surface area measurements (Table 2, Supplement 1). To calculate the paleo-sediment residence time, we used an equation modified from that of the comminution age presented in DePaolo et al. (2006).

The sediment residence time at the time of deposition (i.e. paleo-sediment residence time) is defined as follows:

$t_{\text {res }}=-\frac{1}{\lambda_{234}} \ln \left[\frac{A_{\text {dep }}-\left(1-f_{\text {pre }}\right)}{A_{0}-\left(1-f_{\text {pre }}\right)}\right]$

where $\lambda_{234}$ is the ${ }^{234} \mathrm{U}$ decay constant (in $\left.\mathrm{yr}^{-1}\right), A_{\text {dep }}$ and $A_{0}$ are the $\left({ }^{234} \mathrm{U} /{ }^{238} \mathrm{U}\right.$ ) activity ratios (unitless) at the time of deposition and at time zero (i.e. onset of comminution in the weathering profile), respectively, $f_{\text {pre }}$ is the recoil loss factor prior to deposition (unitless), i.e. the fraction of ${ }^{234} \mathrm{U}$ that is recoiled out of mineral grains.

The measured $\left({ }^{234} \mathrm{U} /{ }^{238} \mathrm{U}\right)$ activity ratio is then defined as follows:

$A_{\text {meas }}=\left(1-\mathrm{f}_{\text {post }}\right)+\left[A_{\text {dep }}-\left(1-\mathrm{f}_{\text {post }}\right)\right] e^{\lambda_{234} t_{d e p}}$

where $f_{\text {post }}$ is the recoil loss factor post-deposition and $t_{d e p}$ is the deposition age (in yr). Thus, equations (1) and (2) can be combined to write: 
$t_{\text {res }}=-\frac{1}{\lambda_{234}} \ln \left[\frac{\left[A_{\text {meas }}-\left(1-f_{\text {post }}\right)\right] e^{-\lambda_{234} t} d e p_{+}\left(1-f_{\text {post }}\right)-\left(1-f_{\text {pre }}\right)}{A_{0}-\left(1-f_{\text {pre }}\right)}\right]$

The recoil loss factor as function the grain surface area is determined as follows (Kigoshi, 1971; Luo et al., 2000):

$$
f=\frac{1}{4} L S \rho
$$

where $L$ is the recoil length of ${ }^{234} \mathrm{Th}$ (30 $\mathrm{nm}$ on average in common silicate minerals; Dosseto and Schaller, 2016), $\rho$ the density of the sediment (taken to be $\left.2.6 \mathrm{~g} / \mathrm{cm}^{3}\right)$, and $S$ the surface area of the sediment $\left(\mathrm{m}^{2} / \mathrm{g}\right.$ ) as measured by gas sorption analysis. Surface roughness at the scale of the adsorbent's molecule diameter (nitrogen, $0.354 \mathrm{~nm}$ ) might result in an overestimation of the recoil loss factor (Maher et al., 2006), which can be resolved by introducing a fractal correction (Bourdon et al., 2009). However, a fractal correction is only required if micro- $(<2 \mathrm{~nm})$ or mesopores $(2-50$ $\mathrm{nm}$ in diameter) are present in the investigated samples (Francke et al., 2018). Gas sorption analyses of our samples show type II isotherms (Supplement 1), which is characteristic for non-porous or macroporous adsorbents. This indicates that a fractal correction is not required for the analyzed samples .

We considered two scenarios for the calculation of sediment residence times using equation (3): (i) no loss of ${ }^{234} U$ followed final deposition $\left(f_{\text {post }}=0\right.$ ) or (ii) loss of ${ }^{234} \mathrm{U}$ at the same rate pre- and post- final deposition $\left(f_{\text {post }}=f_{\text {pre }}\right)$. In each case, sediment residence times were calculated using a Monte Carlo simulation (10,000 simulations). For each sample, $A_{\text {meas }}$ was taken randomly within the range of measured $\left({ }^{234} \mathrm{U} /{ }^{238} \mathrm{U}\right)$ activity ratios and its error as provided in Table 2, and $A_{0}$ was taken randomly between 1 and 1.1 to account for a parent material not in secular equilibrium (Handley et al., 2013). For samples where S was not measured, it was taken randomly between the minimum and maximum values measured (Table 2).

\section{Results and Discussion}

\subsection{Chronology, Sedimentology, and proxies}

\subsubsection{Tephrochronology and age model}

More detailed chronostratigraphic considerations are required for this study as the published chronological frame work for the upper $243 \mathrm{mcd}$ of the DEEP site sediments is based on only one cryptotephra horizon (OH-DP-0027/Mercato, Leicher et al., 2016) for the interval presented herein (Francke et al., 2016; Leicher et al., 2016). Extensive tephrostratigraphic work on sediments of Lake Ohrid and nearby Lake Prespa documents the occurrence of several cryptotephra horizons intercalated in the Late Glacial to Holocene, hemi-pelag ic sediments of both lakes (Wagner et al., 2008; Sulpizio et al., 2010; Vogel et al., 2010c; Damaschke et al., 2013; Leicher et al., 2016), however, they have not been all described for the sediments of the DEEP site sequence. In addition to the previously described cryptotephra horizon (OH-DP-0027/Mercato), three new cryptotephra horizons were found by their characteristic signal in DEEP site sediment's high-resolution XRF core scanning data and by subsequent microscopic inspection of the respective intervals (Table 1, Supplement 3). The geochemical characterisation, tephrostratigraphy and tephrochronology of the three unknown cryptotephra horizons OH-DP-0049, OH-DP-0015, and OH-DP-0009, which are correlated to the LN1, FL, and AD472/512 eruptions, respectively, are presented and discussed in detail in the supplementary information (Table 1, Supplement 2,3,4).

The LN1, Mercato, FL, and AD472/512 cryptotephra horizons (Table 1) and tephra layer OH-DP-0115 (correlated to the Y-3 tephra layer by Leicher et al., 2016) were used to establish a robust skeleton for the chronology for the upper $5.51 \mathrm{mcd}$ of the DEEP site sequence (Fig. 3). In addition, three age-tie points were introduced to better constrain the 
event (Table 1, Fig. 3A, see supplement for detailed discussion). Both climate events are well-constrained for the Balkan Peninsula and have been described in various sedimentary and pollen records from lakes Ohrid (Wagner et al., 2009; Vogel et al., 2010a; Wagner et al., 2012), Prespa (Wagner et al., 2010; Aufgebauer et al., 2012; Panagiotopoulos et al., 2013), and Dojran (Francke et al., 2013; Masi et al., 2018). Ages for the onset and end of the YD were extracted from synchronized Greenland ice core records (Table 1, Rasmussen et al., 2014, see supplement for more detailed discussions).

The age-depth model between the Y-3 tephra layer and the sediment surface was calculated with the software package Bacon 2.2 by Blaauw and Christen (2011). The obtained age model was then cross evaluated with the chronological framework for Lake Prespa sediments (Fig. 3B), where the time interval investigated herein is constrained by four tephrostratigraphic and 13 radiocarbon age tie points (Damaschke et al., 2013). Total tree pollen percentages and $\mathrm{K}$ (Potassium) intensities of both cores show an excellent agreement (Fig. 3B). Discrepancies between the records during the onset of the YD are attributed to the introduced age tie point at $12,850 \pm 100$ cal yr BP, which is not included in the Prespa chronology.

The age model indicates that the sediments of the DEEP site sequence above 5.51 med cover the last $\sim 16,000$ years. Sedimentation rates vary between $0.07 \mathrm{~cm} / \mathrm{yr}$ and $0.016 \mathrm{~cm} / \mathrm{yr}$, and average $0.04 \mathrm{~cm} / \mathrm{yr}$. Overall higher sedimentation rates persisted during the Last Glacial, a short time interval prior to the 8.2 cooling event, and the Late Holocene after $\sim 3,000$ cal yr BP. Adjusted for uncertainties in our chronology, we herein follow the chronostratigraphic classification of Ras mussen et al. (2014) for the Bølling/Allerød (B/A, 15,000 to 12,850 cal y r BP) and YD (12,850 to $11,600 \mathrm{ca}$ yr BP). We then follow the recently (2018/07) updated chronostratigraphy of the International Commission on Stratigraphy for the Holocene and refer to the Early (Greenlandian, 11,600 to 8,200 cal yr BP), Mid- (Northgrippian, 8,200 to 4,200 cal yr BP) and Late (Meghalayan, 4,200 cal yr BP to present) Holocene in the text.

\subsubsection{Lithology}

The lithology of the DEEP site sediments is classified by Francke et al. (2016) by the amount of calciu m carbonate $\left(\mathrm{CaCO}_{3}\right.$, mainly calcite), which is predominantly of endogenic origin as shown previously (Francke et al., 2016; Lacey et al., 2016). We use TIC contents and $\mathrm{Ca}$ intensities as an estimate of calcite content, as there is a negligible contribution from early diagenetic and/or detrital carbonates in this core section (Francke et al., 2016; Lacey et al., 2016).

TIC ( $<2$ wt. \%) and $\mathrm{Ca}$ are low to negligible between $\sim 16,000$ and $\sim 8,000$ cal $\mathrm{yr}$ BP and thus, the sediments are classified as silty clay (TIC < 0.2 wt. \%, lithotype 3 sediments after the classification of Francke et al., 2016, Fig. 4) and slightly calcareous silty clay (TIC between 0.2 and $2 \%$, lithotype 2). TOC content, a measure for the amount organic matter (OM) which is finely dispersed (macroscopic plant remains are absent; Francke et al. (2016)), is variable between $\sim 16,000$ and $\sim 8,000$ cal yr BP and values $>5 \mathrm{wt} . \%$ are restricted to the time interval between $\sim 9,000$ and $~ 8,500$ cal yr BP. Late Glacial to Early Holocene sediment composition is balanced by moderate to high amounts of clastic matter, as inferred from moderate to high $\mathrm{K}$ intensities.

TIC content and $\mathrm{Ca}$ intensity are overall high after $\sim 8,000 \mathrm{cal}$ yr BP and the deposits are mainly attributed to lithotype 1 sediments (calcareous silty clay) with TIC content $>2$ wt. \% (Fig. 4). Lithotype 2 sediments are restricted to a short interval at $\sim 1,250$ cal y r BP. Overall moderate to low a mounts of OM and variable amounts of clastic matter balance the sediment composition during the Mid-and Late Holocene. Event layers, such as macroscopic tephra layers or mass wasting deposits, are absent in the sediments of the DEEP site sequence between $\sim 16,000$ cal yr BP and present day. Calcite deposition in Lake Ohrid sediments is mainly controlled by photosynthesis-induced formation of endogenic crystals in the epilimnion when spring and summer temperatures are high, and as long as there is a sufficient supply of $\mathrm{Ca}^{2+}$ and $\mathrm{HCO}_{3}{ }^{-}$ions (Wagner et al., 2009; Vogel et al., 2010a; Francke et al., 2016). Supply of $\mathrm{Ca}^{2+}$ and $\mathrm{HCO}_{3}{ }^{-}$ions 
and by recycling (mixing) from lower parts of the water column. Calcite dissolution might have been promoted during times of low winter temperatures, when improved mixing led to decomposition of $\mathrm{OM}$ and lower $\mathrm{pH}$ values in the bottom waters (Francke et al., 2016; Lacey et al., 2016).

Rock-Eval pyrolysis on the Late Glacial to Holocene record from the nearby LINI drill site (Fig. 2 for location) suggests that OM in Lake Ohrid's sediments is predominately of aquatic origin (Lacey et al., 2015), whereas lipid biomarker analyses on cores Co1202 (Holtvoeth et al., 2010; Holtvoeth et al., 2017) and Lz1120 (Holtvoeth et al., 2010; Holtvoeth et al., 2015, cf Fig. 2 for locations) revealed that terrestrial OM from soils and leaf litter do minate the OM pools close to major inlets. Zanchetta et al. (2018) discussed that OM of the DEEP site in the central part of the lake is predominantly of aquatic origin, as indicated by the correspondence between $\delta^{13} \mathrm{C}_{\text {org }}$ and $\delta^{13} \mathrm{C}_{\text {carb }}$ during the last $\sim 500$ kyrs. This correspondence might suggest that the isotope compositions of $\mathrm{OM}$ and endogenic calcite are controlled by the same (aquatic) carbon cycle, which is also supported by a comparison between LINI's normalized $\delta^{13} \mathrm{C}_{\mathrm{org}}$ and $\delta^{13} \mathrm{C}_{\mathrm{carb}}$ data (Supplement 5 and Lacey et al., 2015). Similar carbon sources for both is otopes imply that the organic carbon is mainly of aquatic origin. The amount of aquatic OM depends on the primary productivity in the water column, which is controlled by nutrient supply from the catchment, surface runoff, spring and summer temperatures, and by decomposition of OM.

Titanium (Ti) mainly occurs in insoluble mineral phases and is principally associated with fine-grained, silt- to claysized clastic matter in Lake Ohrid sediments (Vogel et al., 2010a). K is mobilized during chemical weathering and aqueous $\mathrm{K}$ is taken up in the interlayer spaces of phyllosilicates, in interstitial sites of calcite, and adsorbs on to clay surfaces and organic matter (Ishikawa and Ichikuni, 1984; Boek et al., 1995; Pal et al., 1999). Clay minerals in Lake Ohrid's sediments comprise between 40 and $70 \%$ of clay minerals with interlayered structures, such as illite and vermiculite (Lézine et al., 2010). Interlayered clay minerals have a great potential for K fixation compared to clay minerals with low charge, such as kaolinite (Pal et al., 1999). Thus, the $\mathrm{Ti} / \mathrm{K}$ ratio can provide insights into the mobilisation of $\mathrm{K}$, chemical alteration of detrital matter, and/or grain size sorting in Lake Ohrid sediments.

\subsubsection{Pollen Data}

We here present and discuss high-resolution pollen data for the Late Glacial to Holocene part of the DEEP site sediments in the light of the study by Sadori et al. (2016), who presented vegetation data at low resolution for the last 500 kyrs with a particular focus on orbital climate variability. Total trees versus herbs pollen percentages account for $100 \%$ of the counted pollen taxa, and represent the relative abundance of tree pollen in the counted taxa. In the investigated time interval herein, the tree versus herb pollen percentages vary between $\sim 33$ and $\sim 94 \%$ (i.e. 33 to $94 \%$ tree pollen taxa). Values between $\sim 33$ and $\sim 50 \%$ are restricted to the time interval between $\sim 16,000$ and $\sim 15,000 \mathrm{cal} \mathrm{yr}$ $\mathrm{BP}$, and to the YD climate oscillation (Fig. 4). Late Glacial tree pollen percentages above $50 \%$ are associated with the Bølling/Allerød (B/A). Highest tree pollen percentages (values $>90 \%$ ) occur after $\sim 8,500$ cal $\mathrm{yr} \mathrm{BP}$, and begin to decrease between 4,250 and $\sim 3,500$ cal yr BP. Cultivated pollen taxa include Juglans, Olea, and Cerealia, are widespread indicators of increasing human activity in the Mediterranean area (Mercuri et al., 2013; Panagiotopoulos et al., 2013; Masi et al., 2018) and y ield values of up to 10\% during the investigated time interval. High percentages of cultivated pollen taxa during the Late Glacial and Early Holocene are mainly associated with a high contribution of Cerealia, which occur naturally in grasslands in the region prior to any farming and agricultural activity within the Late Holocene (Panagiotopoulos et al., 2013).

Published pollen records from Lake Ohrid's DEEP site sequence (Sadori et al., 2016), core Lz1120 located in the south-eastern corner of Lake Ohrid (Wagner et al., 2009, Fig. 1), and nearby Lake Prespa (Panagiotopoulos et al., 2013) revealed that high tree pollen percentages are broadly associated with warmer and wetter climate conditions on the Balkan Peninsula, whereas high herb pollen percentages coincides with colder and drier conditions. 
within the Prespa and Ohrid basins in response to climate warming and increased rainfall. During the Late Holocene, a decrease in tree pollen percentages as well as maxima in cultivated and ruderal taxa percentages point to humaninduced wood clearance related to agriculture and animal husbandry such as reported from lakes Ohrid (Wagner et al., 2009), Prespa (Panagiotopoulos et al., 2013), and Dojran (Masi et al., 2018).

\subsubsection{Carbon is otopes}

Late Glacial to Holocene $\delta^{13} \mathrm{C}_{\text {org }}$ values fluctuate between -26 and $-29 \%$ since $\sim 16,000$ cal yr BP. Late Glacial $\delta^{13} \mathrm{C}_{\text {org }}$ responds to climate variability associated with the B/A and YD climate oscillations with prevailing higher values during warmer and wetter intervals, and lower $\delta^{13} \mathrm{C}_{\text {org }}$ during cold and dry periods. The Early and Mid-Holocene are characterized by decreasing $\delta{ }^{13} \mathrm{C}_{\mathrm{org}}$ from -26 to $-29 \%$, encompassing the maximum amplitude observed in the data. $\delta^{13} \mathrm{C}_{\text {org }}$ increases to $-27 \%$ between $\sim 4,000$ and $\sim 1,000$ cal yr BP, and remains variable thereafter.

As $\mathrm{OM}$ in the DEEP site sediments is thought to be predominantly of aquatic origin, $\delta^{13} \mathrm{C}_{\text {org }}$ mainly reflects past variability in the aquatic carbon cycle (Zanchetta et al., 2018). The isotope composition of Lake Ohrid's total dissolved inorganic carbon (TDIC) pool is mainly controlled by (i) exchange with atmospheric $\mathrm{CO}_{2}$, (ii) the supply of $\mathrm{HCO}_{3}{ }^{-}$ ions from carbonate rocks via the karst system, (iii) the recycling of carbon from surface sediments and (iv) supply of (dissolved) soil-derived $\mathrm{CO}_{2}$. The former two processes promote high $\delta^{13} \mathrm{C}_{\mathrm{TDIC}}$ values while the latter two favour low $\delta^{13} \mathrm{C}_{\mathrm{TDIC}}$ (Leng et al., 2010; Lacey et al., 2015; Zanchetta et al., 2018). Zanchetta et al. (2018) showed that lower $\delta^{13} \mathrm{C}_{\mathrm{org}}$ in the DEEP site sediments during warmer (interglacial) periods over the last 500 kyrs is mainly driven by enhanced supply of soil-derived $\mathrm{CO}_{2}$. This relationship may be mediated by improved mixing during colder intervals, which promotes the release of ${ }^{13} \mathrm{C}$-depleted carbon from the surface sediments, and by isotopic exchange with ${ }^{13} \mathrm{C}$ enriched atmospheric $\mathrm{CO}_{2}$ in warmer and drier, and thus, more evaporative climates.

\subsubsection{Uranium isotopes and paleo-sediment residence time}

DEEP site sediment $\left({ }^{234} \mathrm{U} /{ }^{238} \mathrm{U}\right)$ activity ratios vary between 0.898 and 0.984 in the investigated time interval and show a distinct shift from values $>0.92$ between $\sim 16,000$ and $\sim 8,500$ cal yr BP to lower values subsequently. This shift corres ponds well with the first occurrence of lithotype 1 deposits and with higher tree pollen percentages $(>90 \%)$ after $\sim 8,500$ cal yr BP (Fig. 4).

Lower $\left({ }^{234} \mathrm{U} /{ }^{238} \mathrm{U}\right)$ activity ratios record storage in soils on the hillslope, fluvial transport, alluvial temporary storage, and final deposition as ${ }^{234} \mathrm{U}$ is continuously depleted from fine-grained detrital matter. In a weathering horizon, $\left({ }^{234} \mathrm{U} /{ }^{238} \mathrm{U}\right)$ activity ratios decrease in shallower depths as new regolith material is produced close to the bedrockregolith interface, which consequently migrates downwards over time (Dosseto et al., 2008b; Ma et al., 2010; Suresh et al., 2013; Gontier et al., 2015; Rothacker et al., 2018). As a result, the elapsed time of storage is much shorter for finegrained material close to the bedrock-regolith interface (high $\left({ }^{234} \mathrm{U} /{ }^{238} \mathrm{U}\right.$ ) activity ratios) than for detrital matter of topsoil layer (low $\left({ }^{234} \mathrm{U} /{ }^{238} \mathrm{U}\right)$ activity ratios). Mobilisation of detrital matter with high $\left({ }^{234} \mathrm{U} /{ }^{238} \mathrm{U}\right)$ activity ratios (referring to relatively new material) is therefore the result of deep erosion (such as gullying, mass wasting). Shallow sheet wash erosion in turn promotes mobilisation of detrital matter with low $\left({ }^{234} \mathrm{U} /{ }^{238} \mathrm{U}\right)$ activity ratios. The Uranium is otope ratio is furthermore modulated by the thickness of the weathering or soil horizon. Lower (higher) activity ratios occur particularly in the topsoil layer of thick (thin) soils, indicating longer (shorter) sediment storage. The $\left({ }^{234} \mathrm{U} /{ }^{238} \mathrm{U}\right.$ ) activity ratios can therefore be used as a proxy for deep erosion of thin soils versus shallow erosion of thick soils, and/or sheet wash versus gully and/or mass wasting erosion (cf also Rothacker et al., 2018).

Following hills lope erosion and the subsequent export into the alluvial system, further lowering of $\left({ }^{234} \mathrm{U} /{ }^{238} \mathrm{U}\right)$ activity ratios can occur during alluvial transport and storage if this takes place over more than a few 10,000's yr (Dosseto et al., 2006; Granet et al., 2007; Chabaux et al., 2008; Granet et al., 2010). In the relatively small catch ment of Lake 
takes place during storage in the weathering horizon, storage in the unconsolidated sediments forming the wide plain s to the north and south of the lake, and after final deposition in the lake basin. The erosive force of s mall creeks draining the wide plain areas is likely very weak as the slope incline is very low and extensive channel migration is not observed at present. This might imply that remobilisation of old, ${ }^{234} \mathrm{U}$-depleted, unconsolidated deposits from these plains is likely to have a minimal role on the sediment budget of Lake Ohrid. However, remobilisation of alluvial sediments deposited at the lake margins could have occurred by wave action during periods of higher lake levels and flooding (Holtvoeth et al., 2017). This could contribute to lower $\left({ }^{234} \mathrm{U} /{ }^{238} \mathrm{U}\right)$ activity ratios in DEEP site sediments. Considering that the catchment geology is dominated by limestones in the eastern and northwestern parts of the basin, that major creeks in these limestone-dominated areas are lacking and that detrital carbonate concentrations in the DEEP site sediments are negligible (Lacey et al., 2016), supply of ${ }^{234}$ U-depleted clastic matter to the lake originates from the southwestern and northeastern catchment. This is also supported by modern total sediment yield data ( $\mathrm{t} / \mathrm{yr}$ ) as shown in Figure 2 (Vogel et al., 2010b) and implies that abrasion in the Galičica Mountain range, consisting exclusively of marine carbonate rocks, does not impact the $\left({ }^{234} \mathrm{U} /{ }^{238} \mathrm{U}\right)$ activity ratios in the lacustrine deposits.

As described above, sediment residence times were calculated in order to account for any grain size variability control on $\left({ }^{234} \mathrm{U} /{ }^{238} \mathrm{U}\right)$ activity ratios. A comparis on of $\left({ }^{234} \mathrm{U} /{ }^{238} \mathrm{U}\right)$ activity ratios to grain size distributions from the same samples shows no direct correspondence (Supplement 6), however, the shape and roughness of detrital grains might still control loss of ${ }^{234} \mathrm{U}$, such as that we herein combine uranium isotope and gas sorption analyses (see Table 2 and Supplement 1 for results of gas sorption analyses).

The two tested scenarios for estimating the sediment residence time assuming (i) no ${ }^{234} \mathrm{U}$ loss after final deposition or (ii) constant ${ }^{234} \mathrm{U}$ loss pre- and post- final deposition yield sediment residence times within error of each other for most samples (Supplement 6). No loss of ${ }^{234} \mathrm{U}$ after final deposition might occur if detrital grains are densely compacted and surrounding pore space is smaller as the recoil distance of ${ }^{234} \mathrm{Th}$. The consistent results of estimated sediment residence times within error of each other is a consequence of the young deposition age, such that hypothesizing about ${ }^{234} \mathrm{U}$ behaviour post-deposition has little impact on calculated residence times. Nevertheless we consider scenario (ii) to be more likely because Lake Ohrid sediments have water content ranging between 54\% and 74\% (Supplement 6), and so loss of recoiled ${ }^{234} \mathrm{U}$ can still occur post-deposition.

\subsection{Climate history, landscape and soil system evolution}

In this section, we first provide a brief overview of the paleoclimate signal (pollen, TIC, Ca) in the first paragraph of each sub-section. Extensive Late Glacial to Holocene paleoclimatic data inferred from Lake Ohrid sediments (e.g. Belmecheri et al., 2009; Wagner et al., 2009; Vogel et al., 2010a) and nearby lakes Prespa (e.g. Aufgebauer et al., 2012), Maliq (e.g. Bordon et al., 2009), and Dojran (e.g. Francke et al., 2013) are available in the literature. Late Glacial to Holocene landscape and soil system evolution on the Balkan Peninsula is then reconstructed in the following paragraphs using innovative uranium isotope and paleo-sediment residence time data in concert with carbon is otopes $\left(\delta^{13} \mathrm{C}_{\mathrm{org}}\right)$, ele mental ratios $(\mathrm{Ti} / \mathrm{K})$, sedimentation rates, and pollen data as inferred from the sediments of the DEEP site.

\subsubsection{Late Glacial $(16,000$ until 11,600 cal yr BP)}

Low tree pollen percentages between $\sim 16,000$ and $\sim 15,000$ cal yr BP and during the YD period imply overall cold and dry climates. Warmer and wetter conditions are indicated by higher tree pollen percentages during the B/A climate oscillation (Fig. 4). Close woodland vegetation was most likely restricted to lower elevations within the Ohrid-Prespa basin during the Late Glacial although expansions of arboreal vegetation in response to climate warming during the B/A led to an altitudinal upward migration of vegetation belts (Panagiotopoulos et al., 2013, Fig. 4). Owing to the 
and preceding glacial stages, no significant migration time lag is observed (Panagiotopoulos et al., 2013; Panagiotopoulos et al., 2014; Sadori et al., 2016). Overall low TIC and Ca and the presence of lithotype 2 and 3 deposits record low spring and summer temperatures, restricted ion supply from the karst system, and mineral dissolution due to improved mixing during winter (Vogel et al., 2010a). High TOC content during the B/A are consistent with improved primary productivity in the epilimnion driven by enhanced nutrient supply from the catchment under warmer and wetter conditions (Vogel et al., 2010a).

The higher $\left({ }^{234} \mathrm{U} /{ }^{238} \mathrm{U}\right.$ ) activity ratios and shorter residence times (med ian value: $34 \pm 7 \mathrm{ky} \mathrm{rs,} \mathrm{n}=6$ ) during the wetter and more densely vegetated B/A compared to the drier conditions up to $\sim 15,000$ cal yr BP $(42 \pm 8$ kyrs, $n=3)$ and during the YD (39 \pm 7 ky rs, n=5, Fig. 4) suggest that erosion processes are most likely controlled by rainfall. Hillslope stabilis ation by a dense forest canopy that expanded during the B/A (higher tree pollen percentages) plays only a minor role. The data suggest removal of the topsoil layer (low $\left({ }^{234} \mathrm{U} /{ }^{238} \mathrm{U}\right.$ ) activity ratios) by prevailing shallow erosion (such as sheet wash) in dry conditions (up until $15,000 \mathrm{cal} \mathrm{yr}$ BP, YD) and mobilisation of deeper soil horizons (high $\left({ }^{234} \mathrm{U} /{ }^{238} \mathrm{U}\right)$ activity ratios) in wetter conditions (B/A). As discussed above, further lowering of $\left({ }^{234} \mathrm{U} /{ }^{238} \mathrm{U}\right)$ activity ratios controlled by alluvial transport and storage beyond the millennial-scale is unlikely to play a major role at Lake Ohrid. No major transgressions are reported at Lake Ohrid for the Late Glacial (Lindhorst et al., 2010), which also contradicts mobilisation of detrital matter by wave action and transgressive soil erosion. We thus infer that $\left({ }^{234} \mathrm{U} /{ }^{238} \mathrm{U}\right)$ activity ratios and residence times mainly record a signal of local hillslope erosion. Deep hillslope erosion was promoted at altitudes above dense forest vegetation where soils are relatively thin (further promoting high $\left({ }^{234} \mathrm{U} /{ }^{238} \mathrm{U}\right)$ activity ratios), where precipitation was most likely higher (Panagiotopoulos et al., 2013), and where a high slope angle promotes deep erosion (Fig. 5). The closed forest vegetation at low elevations is a result of the refug ial character of the Ohrid-Prespa basin (Fig. 4, 5, and Panagiotopoulos et al., 2013; Sadori et al., 2016) and would stabilize soils on the flat sedimentary plains and in the lowermost parts of hillslopes. Longer residence times between $\sim 16,000$ and $\sim 15,000$ cal yr BP and during the YD consequently indicate shallower hillslope erosion of thicker soils, which could have formed underneath the tree canopy that persisted even during glacial times (Fig. 5). The reconstructed drop in winter rainfall driving lower annual precipitation during the YD at nearby paleolake Maliq (Bordon et al., 2009) furthermore implies that erosion from $\mathrm{higher} \mathrm{elevations} \mathrm{could} \mathrm{have} \mathrm{been} \mathrm{controlled} \mathrm{by} \mathrm{winter} \mathrm{precipitation} \mathrm{and} \mathrm{snowmelt} \mathrm{on} \mathrm{annual}$ time scales, as less severe spring snowmelt events would have hampered deep erosion of thin soils above the tree line.

Overall high $\delta{ }^{13} \mathrm{C}_{\mathrm{org}}$, indicating restricted supply of ${ }^{12} \mathrm{C}$-enriched soil-derived $\mathrm{CO}_{2}$ from the catchment, imply that soil development was rather limited and probably restricted to lower elevations during the Late Glacial. Lower $\delta^{13} \mathrm{C}_{\mathrm{org}}$ under glacial boundary conditions, such as until 15,000 cal yr BP and during the YD, was controlled by carbon recycling from the surface sediments (Zanchetta et al., 2018). Limited soil development and restricted mobilisation of $\mathrm{K}$ by chemical weathering is also consistent with overall high $\mathrm{Ti} / \mathrm{K}$.

\subsubsection{Early Holocene (11,600 until 8,200 cal yr BP)}

Early Holocene tree pollen percentages and TOC contents record increasing temperatures, rainfall and altitudinal upward migration of the vegetation belts in response to climate warming after termination I. Low TIC and Ca abundances, and the presence of lithotype 2 and 3 sediments, are inconsistent with higher temperatures and are thus attributed to limited availability of dissolved $\mathrm{Ca}^{2+}$ and $\mathrm{HCO}_{3}{ }^{-}$ions due to restricted supply from the karst system and/or restricted mixing. The impact of Lake Prespa is difficult to assess but increasing water levels at Prespa promoting ion and nutrient supply to Lake Ohrid did not culminate before the end of the Early Holocene (Cvetkoska et al., 2014).

Early Holocene sediment residence times $(30 \pm 7 \mathrm{kyrs}, \mathrm{n}=5)$ and $\left({ }^{234} \mathrm{U} /{ }^{238} \mathrm{U}\right)$ activity ratios imply that wetter climates promoted deep erosion of thin soils above the tree line (Fig. 4, 5), similar as discussed for the B/A period. Humid Early Holocene conditions, characterised by Mediterranean-type rainfall distributions and mild winter temperatures 
during winter and increased melt water discharge during spring. High melt water discharge at high elevations can promote deep erosion of thin soils, further promoting short sediment residence times. The shortest residence times at $\sim 10,250$ cal yr BP mark the culmination of long-term deeper erosion and/or erosion progressively dominated by detrital matter from thin soils at high altitudes, as observed since the onset of the analysed interval. Gradual expansion of the vegetation cover at higher altitudes might have progressively stabilized hillslopes and restricted landscapes vulnerable to deep erosion (high activity ratios) to high altitudes, where soils were less thick (Fig. 5). This indicates that the density of the vegetation cover modulates the relationship between erosion depth and rainfall. Hillslope stabilisation in correspondence with altitudinal expansion of the vegetation belts and less mobilisation of detrital matter is further supported by sedimentary proxy data, which imply less clastic matter supply to the lake as the sedimentation rate drops while OM concentration increases (Fig. 4).

Decreasing $\delta{ }^{13} \mathrm{C}_{\mathrm{org}}$, which is indicative for supply of ${ }^{13} \mathrm{C}$-depleted, soil-derived $\mathrm{CO}_{2}$, implies increasing soil development during the Early Holocene, whereas significant che mical alteration of detrital matter (decreasing Ti/K) is not observed until the end of the Early Holocene. The delayed response of $\mathrm{Ti} / \mathrm{K}$ might imply that $\mathrm{CO}_{2}$ production in the soil profiles responded rapidly to the expansion of dense woodland vegetation (increasing tree pollen percentages) compared to a delayed traceable increase of chemical weathering in the catchment. Lower $\delta^{13} \mathrm{C}_{\text {org }}$ could be further promoted by deposition of terrestrial OM (C-3 plants) in Lake Ohrid, which is consistent with increasing trees versus herbs pollen percentages.

\subsubsection{Mid-Hol ocene $(8,200$ until 4,200 cal yr BP)}

Overall warm and hu mid conditions are inferred for the Mid-Holocene from high tree versus herbs pollen percentages. High temperatures and sufficient ion supply from the karst catchment are further supported by high TIC (up to $8 \%$ ) and $\mathrm{Ca}$, and are consistent with higher Mid-Holocene lake levels at Lake Prespa (Cvetkoska et al., 2014). A high lake level at Prespa promotes dissolved ion supply to Lake Ohrid. The warm and humid conditions were perturbed by the 8.2 cooling event, which is clearly evident in several regional paleoclimate records (Wagner et al., 2008; e.g. Aufgebauer et al., 2012; e.g. Panagiotopoulos et al., 2013; Lacey et al., 2015) and expressed in the DEEP site by high $\mathrm{K}$ intensities and lower tree pollen percentages (Fig. 4). Mid-Holocene climate conditions subsequent to the 8.2 cooling event are commonly considered to be very stable on the Balkan Peninsula (e.g. Aufgebauer et al., 2012). A second decrease in trees versus herb pollen percentages at $\sim 6,750$ cal yr BP is potentially associated with a cold and dry event at either 7,000 or 6,400 cal y r BP as reported from the Adriatic Sea (Co mbourieu-Nebout et al., 2013), given the uncertainties in both chronologies. But this event is not recorded in tree versus herb pollen percentages from nearby Lake Prespa (Fig. 4, Panagiotopoulos et al., 2013). A change to an increasingly drier climate (e.g. Leng et al., 2010; Combourieu-Nebout et al., 2013; Lacey et al., 2015) and/or increasing seasonality in precipitation (e.g. Combourieu-Nebout et al., 2013), has frequently been described in stable isotope records from the region after $\sim 6,000$ cal yr BP.

The onset of the Mid-Holocene marks a dramatic shift in $\left({ }^{234} \mathrm{U} /{ }^{238} \mathrm{U}\right)$ activity ratios to lower values, inferring longer sediment residence times ( $52 \pm 7$ kyrs, n=5, Fig. 4). This could reflect a change to shallower erosion across the catchment or a sediment budget dominated by erosion of hillslopes with a thicker soil cover. The low $\left({ }^{234} \mathrm{U} /{ }^{238} \mathrm{U}\right)$ activity ratios at the onset of the Mid Holocene can only partly be attributed to shallow erosion or erosion of thicker soils associated with drier conditions during the 8.2-cooling event as similar values are observed afterwards. Decreasing $\mathrm{Ti} / \mathrm{K}$ might imply that the higher $\delta{ }^{13} \mathrm{C}_{\mathrm{org}}$ during the 8.2 event are rather explained by a reduction in the supply of soil-derived $\mathrm{CO}_{2}$ and or terrestrial $\mathrm{OM}$ from the catchment due to less runoff in overall drier climates then by reduced soil development. Less runoff from the catchment reduces the supply of ${ }^{12} \mathrm{C}$ to the lake, which would promote higher $\delta^{13} \mathrm{C}_{\text {org }}$. 
sediment residence times. Overall drier Mid-Holocene climate conditions (compared to the Early Holocene) are unlikely as a potential explanation for hillslope stabilisation after 8,200 cal yr BP, as gradual drying does not occur until 6,000 cal yr BP (Lacey et al., 2015). The timing of the shift coincides well with widespread forest development in the Lake Ohrid catchment as seen by tree pollen percentages $>90 \%$ in the DEEP site record, and high tree pollen percentages at nearby Lake Prespa (Fig. 4 Panagiotopoulos et al., 2013). In contrast with our findings for the YD and B/A oscillation, sediment residence times are longer during the time of dense woodland expansion (tree pollen percentages $>90 \%$ ), which supports that vegetation cover rather than rainfall controls hillslope erosion during the Early to Mid-Holocene transition. As the natural tree line has been estimated to be located at $\sim 2,200 \mathrm{~m}$ asl in the Prespa basin at present (Panagiotopoulos et al., 2013), the entire Lake Ohrid catch ment would be covered by forests if human intervention is excluded. A dense vegetation cover, and potentially less snow fall and melt water discharge at higher altitudes might have prevented deep erosion and/or mobilisation of detrital matter from thin soils at high elevation (Fig. 5). This is also supported by Mid-Holocene sedimentation rates similar to those of the Early Holocene despite higher authigenic matter concentrations (mainly lithotype 1) with TIC content of up to 7\% (equivalent to $\mathrm{CaCO}_{3}$ content of up to $\sim 60 \%$ ). This implies less deposition of clastic matter in the depo-centre of the lake. Low clastic matter supply also suggests that a major transgressive event during the Mid-Holocene (Lindhorst et al., 2010) played only a minor role on catchment-wide erosion processes. Considerable deposition of older, re-mobilized lacustrine material in the depo-centre of the lake is also inconsistent with the number of corroded/re-deposited pollen grains encountered.

In summary, Late Glacial to Mid-Holocene sediment residence times imply a shift from climatic (rainfall) controlled catchment-wide erosion processes during the Younger Dryas, Bølling Allerød, and Early Holocene to vegetation controlled landscape erosion subsequently. Decreasing $\mathrm{Ti} / \mathrm{K}$ and $\delta^{13} \mathrm{C}_{\mathrm{org}}$ over the same interval imply a de-coupling of soil erosion and soil development in the Ohrid basin.

\subsubsection{Late Holocene $(4,200$ cal yr BP to present)}

Climate signals recorded in trees versus herbs pollen percentages and sedimentary proxy data during the Late Holocene are most likely overprinted by intensifying anthropogenic activities in the region, although variable TIC and TOC in other cores from Lake Ohrid have been attributed to the 4.2 cooling event, the Medieval Warm Period (MWP) and the Little Ice Age (LIA, Wagner et al., 2009). Late Holocene anthropogenic disturbances have frequently been described for the Ohrid and Prespa basins and might explain the onset of decreasing trees versus herbs pollen percentages between 4,200 and 3,500 cal yr BP, which culminates after 2,000 cal yr BP (Wagner et al., 2009; Panagiotopoulos et al., 2013).

Higher $\delta^{13} \mathrm{C}_{\text {org }}$ after $\sim 4,200$ cal yr BP imply less supply of soil-derived $\mathrm{CO}_{2}$ from the catch ment, more evaporation and exchange with atmospheric $\mathrm{CO}_{2}$, and/or enhanced deposition of soil organic matter mobilized from the catchment by agricultural activity. Soil degradation is also implied by increasing Ti/K (Fig. 4). $\delta^{13} \mathrm{C}_{\mathrm{org}}$ and Ti/K indicate that humaninduced soil degradation emerged as early as the onset of the Late Holocene. This is much earlier than the recorded rise in cultivated plant taxa in our data after $\sim 2,000$ cal yr BP, but the first Neolithic settlements at nearby lakes Maliq and Orestiás have been dated to $\sim 8,000$ cal yr BP and 7,300 cal yr BP (Fouache et al., 2010; Kouli, 2015).

Sediment residence times (averaging at $58 \pm 7 \mathrm{kyrs}, \mathrm{n}=11$ ) are similar to Mid-Holocene values and do not show evidence of the unprecedented anthropogenic erosion event as they are only slightly higher compared to values observed during the Mid-Holocene. The lack of response in uranium isotopes and sediment residence time to anthropogenic activity could be explained by the large size of the Ohrid basin. Decreasing tree pollen percentages at 2,000 cal yr BP suggest that anthropogenic activities such as forest clearing for creating pastures and logging may have focused on higher elevation areas with thinner soils (short sediment residence time). The pronounced shift 
Lake Ohrid (Wagner et al., 2009), and at nearby lakes Prespa and Dojran (Wagner et al., 2009; Panagiotopoulos et al., 2013; Masi et al., 2018). The decrease in tree pollen is commonly explained by a higher timber demand (mainly Pinus and Abies) during Greek, Roman, and Byzantine occupation of the region. In the Ohrid and Prespa basins, Pinus and Abies are the most important montane conifers and form pure or mixed forest stands at altitudes between 1,800 and 2,200 $\mathrm{m}$ asl at present (Panagiotopoulos et al., 2013). At the same time, agricultural activities (e.g. cereal cultivation) were restricted to the sedimentary plains, where climate conditions are more favourable and where thicker soil horizons developed over time (longer sediment residence time). Additionally, longer residence times might be explained by an overall drier climate during the Late Holocene (Lacey et al., 2015). Drier climates would restrict the mobilisations of deeper soil horizons from thinner soils at higher elevations.

\subsection{Late Glacial and Holocene evolution of catchment erosion on the Balkan Peninsula}

\subsubsection{Pre-anthropogenic impact}

Early to Mid-Holocene increasing soil development in Lake Ohrid's catchment (from Ti/K, $\delta{ }^{13} \mathrm{C}_{\text {org }}$; Fig. 4) is in excellent agreement with decreasing $\mathrm{Li}$ is otope compositions (noted $\delta^{7} \mathrm{Li}$ ) of detrital sediments at nearby Lake Dojran. This decrease in $\delta^{7} \mathrm{Li}$ was interpreted as a higher abundance of secondary (clay) minerals in the lake sediments and soil development in the catchment (Rothacker et al., 2018). At Lake Dojran, the lack of co-variation between soil Li and U isotopes proxies during the Late Glacial to Mid-Holocene was interpreted as a decoupling between soil development and catchment erosion. A similar observation is made at Lake Ohrid with a decoupling between decreasing Ti/K and $\delta{ }^{13} \mathrm{C}_{\text {org }}$ (soil development) and $\mathrm{U}$ is otope composition (catchment erosion).

During the Late Glacial and Early Holocene, both lakes Ohrid and Dojran show deeper (shallower) erosion of thinner (thicker) soils during wetter (drier) intervals. At Lake Ohrid, this is interpreted as a climatic control on erosion, hillslope stabilisation by vegetation playing only a minor role (see above). Enhanced Early Holocene geomorphological activity on the Balkan Peninsula in response to rainfall forcing is also inferred from alluvial and colluvial sediments in the Visoko Basin (Bosnia-Herzegovina, cf. Fig 1 for locations, Dreibrodt et al., 2013), and from increased minerogenic input to poljes in north-west Greece (Vött et al., 2009) and Croatia (Balbo et al., 2006).

At Lake Ohrid, a threshold in catchment erosion is crossed at the onset of the Mid-Holocene where alternation of deep and shallow erosion in the Early Holocene is replaced by continuous shallow erosion for the Mid- and Late Holocene, interpreted as a shift from climatic- to vegetation-controlled erosion. This threshold was not observed in Lake Dojran $\mathrm{U}$ isotope record (Rothacker et a1., 2018), which can potentially be attributed to site-specific settings, such as the inability of the vegetation cover at Lake Dojran to stabilize hillslopes at all altitudes. The fluvial archive from the Visoko Basin records lower geomorphological activity during the Mid-Holocene, which is timely consistent with longer sediment residence times at Lake Ohrid. The discontinuous character of the fluvial deposits, however, hinders a detailed corre lation to the recorded Early to Mid-Holocene threshold detected in our data. Low levels of Mid-Holocene soil erosion have also been inferred from by moderate to low alluvial fill development in the Darma Basin (Northern Greece, Lespez, 2003).

Potassium intensities, used as a proxy for the amount of detrital matter in the sediments and thus for catchment erosion at Lake Prespa (Aufgebauer et al., 2012), show a good correspondence to those of the DEEP site succession (Fig. 3). However, they do not mirror the threshold-like behaviour during the Early to Mid-Holocene transition observed with $\mathrm{U}$ is otopes. The $\mathrm{K}$ intensity in bulk sediment composition is not only controlled by detrital sediment supply but also by mutual dilution between allogenic and authigenic matter (such as OM, endogenic calcite, biogenic silica). Enhanced (reduced) primary productivity, promoting high OM, calcite, and biogenic silica, and/or less (enhanced) decomposition after deposition can consequently promote low (high) detrital matter concentrations in the sediments despite high (low) 
lacustrine sediment successions from lakes Ohrid, Prespa, and Dojran, have frequently be used to infer enhanced catchment erosion (Vogel et al., 2010a; Aufgebauer et al., 2012; Wagner et al., 2012; Francke et al., 2013). However, enhanced erosion is inconsistent with overall cold and dry conditions during the 8.2-event. Uraniu m isotope data from lakes Ohrid and Dojran (Rothacker et al., 2018) suggest restricted erosion and the mobilisation of shallow soil horizons from thick soils during the centennial scale climatic event. This implies that high $\mathrm{K}$ intensities are rather attributed to less authigenic matter in the sediments, which is consistent with lower temperatures, less primary productivity in the water column and/or improved mixing and decomposition after deposition.

\subsubsection{Human impact}

Increasing Ti/K and $\delta^{13} \mathrm{C}_{\mathrm{org}}$ at Lake Ohrid after $\sim 4,200 \mathrm{cal}$ yr BP are interpreted as a consequence of human land use. This pre-dates the unprecedented human-driven erosion event at Lake Dojran (high $\delta^{7} \mathrm{Li}$ and $\left({ }^{234} \mathrm{U} /{ }^{238} \mathrm{U}\right)$ activity ratios, Rothacker et al., 2018). The pattern and amplitude of the proxy response in both records however show excellent agreement. Enhanced supply of allogenic material to Lake Xinias (central Greece) as early as $\sim 4,500 \mathrm{cal}$ yr BP has also been connected to human activity, but the signal might be biased by additional material mobilized by shoreline erosion (Digerfeldt et al., 2007), and by mutual dilution with authigenic matter, as discussed above. First evidences of human-induced soil erosion at the Drama Basin (Northern Greece) have been dated to 3,600 cal yr BP (Lespez, 2003). The different timing recorded could be attributed to inaccuracies in the chronological frame works, a slightly different timing of human perturbations, and/or significantly different local settlement pattern and farming practises between individual sites (Lespez, 2003).

Styllas et al. (2018) pointed out that the unprecedented erosion event at Lake Dojran coincided with overall colder and wetter conditions that resulted in glaciations of high mountain areas at Mount Oly mpus (Greece); thus a combination of human and climatic factors cannot be ruled out. The most recent glaciations in the Galičica Mountains at Lake Ohrid have been dated to the Younger Dryas (Gromig et al., 2018), and glacial features have not been described for the catchment of Lake Dojran. Local palynological and sedimentary studies on sediments at lakes Ohrid, Dojran, and Prespa (Vogel et al., 2010a; Francke et al., 2013; Panagiotopoulos et al., 2013; Masi et al., 2018) do not record a major climate shift that could explain the unprecedented erosion event. A similar pronounced response in soil erosion is not recorded during other Holocene climate events such as the 8.2 and/or 4.2- event, arguing against a climatic control on the erosion event. Conversely, independent evidence for human settlements in the catchment areas of lakes Prespa, Ohrid, and Dojran comes from local palynological (Fouache et al., 2001; Wagner et al., 2009; Panagiotopoulos et al., 2013; Masi et al., 2018) and lipid biomarker (Thienemann et al., 2017) records. Thus, we suggest that anthropogenic impact is the main driver of reduced soil development in the catchment of lakes Ohrid and Dojran (high $\delta^{13} \mathrm{C}_{\text {org }}$, Ti/K, and $\delta^{7} \mathrm{Li}$ ) during the Late Holocene as agricultural soils are most susceptible to soil erosion (Cerdà, 1998). However, we note that an overall wetter climate might have further promoted erosion.

\section{Conclusions}

Uranium isotopes and estimated sediment residence times provide valuable insights into catchment-wide erosion processes on geological time scales and provide a comprehensive picture of past landscape and soil system evolution in response to climate forcing, changes in vegetation cover and human activity, when combined with multi-proxy analyses on the same core. Prior to human occupation, catchment erosion is primarily controlled by the amount of annual rainfall (mainly winter rainfall in Mediterranean-type climate conditions) and changes in the vegetation cover. Rainfall-controlled erosion processes during the Early and Mid-Holocene have frequently been described for the Balkan Peninsula from other fluvial and lacustrine records. Altitudinal migration of vegetation belts and closing of the 
deep erosion to higher altitudes where soils are presumably thinner than at lower elevations.

The uranium isotope shift at the transition between the Early and Mid-Holocene with prevailing shallow sheet wash erosion or mobilisation of material from thicker soil horizons implies an irreversible change in catchment-wide erosion processes. The threshold crossed at the Early to Mid-Holocene transition has not been described in other studies from the Balkan Peninsula, which can be attributed to the discontinuously of most archives. The threshold is attributed to expansion of forests and development of a closed tree canopy, which stabilizes steep hillslopes with a thinner soil cover at high altitudes. Thus, the rainfall-controlled alternation of shallow and deep erosion in the Early Holocene is permanently replaced by vegetation-controlled shallow erosion since the Mid-Holocene. Decreasing $\delta^{13} \mathrm{C}_{\mathrm{org}}$ and $\mathrm{Ti} / \mathrm{K}$ during the Early and Mid-Holocene imply on-going soil development mainly at lower elevations.

The uranium isotope record does not show a similar unprecedented Late Holocene human-driven erosion event that was observed at nearby Lake Dojran (Rothacker et al., 2018). Th is could be attributed to the larger size of Lake Ohrid catchment, which makes it less sensitive to localised disturbances. Moreover, human perturbations probably focused simultaneously on high altitudes (thin soils, short sediment residence time) and the sedimentary plains in the northem and southern parts of the Lake Ohrid basin (longer residence time). Soil degradation at Lake Ohrid during the Late Holocene is stillinferred from increasing $\delta^{13} \mathrm{C}_{\text {org }}$ and Ti/K.

Overall, the multi-proxy approach used here, including novel tools such as uranium isotopes, allows us to identify the controls on catchment erosion and soil development, as well as their varying influence over time. Climate (rainfall) dominates catchment-wide erosion processes during the Late Glacial to Early Holocene, until vegetation and the expansion of a dense woodland (forest) vegetation promotes Mid-Holocene hillslope stabilisation. Late Glacial to Holocene warming promotes soil development over time up until the Late Holocene, when human land use causes significant soil degradation at low elevations.

Data presented herein is available in the supplement and at Pangaea.de

\section{Acknowledgments}

This research was mainly funded by DFG (German Research Foundation) grant FR3783/1-1 (AF), the GeoQuEST Research Centre (AF, University of Wollongong), and ARC (Australian Research Council) Discovery grant DP140100354 (AD). Sedimentary proxy and pollen analyses were carried out under the umbrella of DFG grants WA2109/13 (BW), PA2664/2-2 (KP), and by Grant No. GSGS-2018A-SUH03 of the Graduate School of Geosciences, University of Cologne (SK). The SCOPSCO Lake Ohrid drilling campaign was funded by ICDP, the German Ministry of Higher Education and Research, the German Research Foundation, the University of Cologne, the British Geological Survey, the INGV and CNR (both Italy), and the governments of the republics of Macedonia (FYROM) and Albania. The authors thank Gabriel T. Enge, Lili Yu, and Nick Fitzpatrick for technical support in the lab.

\section{Author contributions}

AF conducted uranium isotope, gas sorption, and (bio-)geochemical proxy analyses and wrote the manuscript with contributions of all co-authors. AD supervised uranium isotope and gas sorption analyses and contributed to data interpretation. NL conducted tephrostratigraphic analyses, provided their interpretation, and wrote the respective sections for the supplement. KP and SK, and KK conducted pollen analyses and contributed to data interpretation. 
(bio-)geochemical proxy analyses and contributed to data interpretation.

\section{Figures}

Fig. 1: Conceptual model of detrital matter transit from source to sink. Depletion of ${ }^{234} \mathrm{U}$ starts in fine-grained detrital matter that is produced as the weathering front on the hills lopes migrates downward over time. Further lowering of the $\left({ }^{234} \mathrm{U} /{ }^{238} \mathrm{U}\right)$ activity ratio occurs in any process related to hillslope and fluvial storage and transport, and during final deposition in a sedimentary basin. The time excluding final deposition represents the paleo-sediment residence time. Modified after Doss eto and Schaller (2016).

Fig. 2: A: Locations of lakes Ohrid and Dojran on the Balkan Peninsula. B: Bathymetric map of Lake Ohrid and geological map of the Lake Ohrid basin. Marked are also the locations of the DEEP site (5045-1) and of sediment successions analysed in previous studies (cf. legend). Black arrows indicate locations of neighbouring lakes Prespa and Maliq. Clastic matter supply (in tyr ${ }^{-1}$ ) refers to present day conditions. Dashed line shows location of profile shown in Fig. 5. Modified from Vogel et al., 2010, Leicher et al., 2016, and Francke et al., 2016.

Fig. 3: A: Age model of the DEEP site sequence between $11.507 \mathrm{mcd}$ and the sediment surface. Ages were calculated using Bacon 2.2. Uncertainties (Gaussian distribution) of calibrated ${ }^{14} \mathrm{C}$ ages from the literature and of the three cross correlation points are given in Table 1. Cryptotephra layers described for the first time in the DEEP site sequence are highlighted in red, (crypto) tephra layers previously described in Leicher et al. (2016) are marked in black. The pronounced peak in $\mathrm{K}$ intensities at $2.257 \mathrm{mcd}$ is correlated to the 8.2 cooling event. Tree pollen percentages were used to constrain the onset and end of the Younger Dryas oscillation. See text for further explanations. B: Comparison between tree pollen and K intensities from Lake Prespa sediments (Aufgebauer et al., 2012; Damaschke et al., 2013; Panagiotopoulos et al., 2013) and the DEEP site sequence between 16,000 cal yr BP and present days. The chronological framework for Lake Prespa's Late Glacial to Holocene interval presented herein is based on four tephrostratigraphic and 13 radiocarbon dating points (Damaschke et al., 2013).

Fig. 4: Lithology, sedimentary (sedimentation rate, TIC, Ca, TOC, and $\mathrm{K}, \mathrm{Ti} / \mathrm{K}$ ), trees versus herbs and cultivated pollen percentages, isotope $\left(\delta^{13} \mathrm{C}_{\mathrm{org}},\left({ }^{234} \mathrm{U} /{ }^{238} \mathrm{U}\right)\right.$ activity ratio), and sediment residence time data of the DEEP site sequence. Box plots for sediment residence time show median (blue bold line), the first (25\%) and third quartiles ( $75 \%$, i.e. the grey box covers $50 \%$ of the probability density function), the lowest (highest) value within the 1.5 interquartile range (IQR) of the lower (upper) quartiles (blue whiskers), and outlier (blue dots) for the time period until 15,000 cal yr BP, the B/A, YD, and the Early, Mid-, and Late Holocene. Grey-shaded box highlights tree versus herb pollen percentages $>90 \%$ for the Lake Ohrid data. Red dotted line show tree versus herb pollen percentages from Lake Prespa (Panagiotopoulos et al., 2013). Time intervals in blue highlight overall colder and drier periods. The lower panel shows the $\left({ }^{234} \mathrm{U} /{ }^{238} \mathrm{U}\right)$ activity ratios and $\delta^{7} \mathrm{Li}$ from a Late Glacial to Holocene sediment record from nearby Lake Dojran (Rothacker et al., (2018)).

Fig. 5: Conceptual model of hills lope erosion during the Late Glacial/Early Holocene and Mid-Holocene. Dashed line in Fig. 2 marks the location of the SW-NE profile. Deep erosion of thin soils prevails at high elevations during the Late Glacial/Early Holocene and shallow erosion of thick soils is restricted to lower altitudes. Upward migrations of the treeline (Panagiotopoulos et al., 2013) promote hills lope stabilisation and shallow erosion of thick soils during the 
the intensity of erosion processes.

\section{Tables}

Table 1. Chronological tie points.

\begin{tabular}{lllll}
\hline Name & Type & Depth (mcd) & Age (cal yr BP) & References \\
\hline Sediment surface & & 0 & $-61.5 \pm 1$ & n/a \\
AD512/472 & cryptotephra & 0.904 & $1,460 \pm 20$ & historic \\
FL & cryptotephra & 1.554 & $3,370 \pm 70$ & $\begin{array}{l}\text { Coltelli et al. (2000); Wagner et al. } \\
\text { (2008) }\end{array}$ \\
8.2 event & tuning & 2.527 & $8,200 \pm 20$ & n/a \\
Mercato* & cryptotephra & 2.775 & $8,530 \pm 100$ & Zanchetta et al. (2011) \\
YD termination & tuning & 3.29 & $11,600 \pm 100$ & Rasmussen et al. (2014) \\
YD onset & tuning & 4.05 & $12,850 \pm 100$ & Rasmussen et al. (2014) \\
LN1 & cryptotephra & 4.917 & $14,750 \pm 520$ & Siani et al. (2004) \\
Y-3* & tephra & 11.507 & $29,050 \pm 370$ & Albert et al. (2015) \\
\hline
\end{tabular}

(Crypto-) tephra layers already described in Leicher et al. (2016) are marked with an asterisk. See text and supplement for detailed discussions.

Table 2. Uranium isotope activity ratio, surface area, and sediment residence times with ( $\left.\mathrm{T}_{\text {res-loss}}\right)$ or without loss of ${ }^{234} \mathrm{U}\left(\mathrm{T}_{\text {res-noloss }}\right)$ after deposition.

\begin{tabular}{|c|c|c|c|c|c|c|}
\hline Sample ID & $\begin{array}{r}\text { Depth } \\
(\mathrm{mcd}) \\
\end{array}$ & $\begin{array}{l}\text { Age } \\
\text { (cal kyr BP) }\end{array}$ & $\left({ }^{234} \mathrm{U} /{ }^{238} \mathrm{U}\right)$ & $\begin{array}{l}\mathrm{S} \\
\left(\mathrm{m}^{2} / \mathrm{g}\right)\end{array}$ & $\begin{array}{l}\mathrm{T}_{\text {res-loss }} \\
\text { (kyrs) }\end{array}$ & $\begin{array}{l}\mathrm{T}_{\text {res-noloss }} \\
\text { (kyrs) }\end{array}$ \\
\hline Co1261-1 & 0.01 & -0.045 & $0.934 \pm 0.004$ & 46.3 & $43.5 \pm 6$ & $43.4 \pm 6$ \\
\hline Co1261-9 & 0.17 & 0.217 & $0.922 \pm 0.002$ & $\mathrm{n} / \mathrm{a}$ & $57.1 \pm 7$ & $57.4 \pm 7$ \\
\hline Co1261-17 & 0.33 & 0.499 & $0.913 \pm 0.003$ & $\mathrm{n} / \mathrm{a}$ & $60.5 \pm 7$ & $61 \pm 7$ \\
\hline Co1261-25 & 0.49 & 0.744 & $0.924 \pm 0.005$ & 42.1 & $52.6 \pm 7$ & $53.4 \pm 7$ \\
\hline Co1261-73 & 0.65 & 1.015 & $0.922 \pm 0.002$ & $\mathrm{n} / \mathrm{a}$ & $56.7 \pm 7$ & $57.8 \pm 7$ \\
\hline Co1261-81 & 0.81 & 1.308 & $0.926 \pm 0.003$ & $\mathrm{n} / \mathrm{a}$ & $57.8+7-8$ & $59.2+7-8$ \\
\hline OH-1 & 0.97 & 1.632 & $0.916 \pm 0.003$ & 38.3 & $59.1 \pm 7$ & $61 \pm 7$ \\
\hline $\mathrm{OH}-2$ & 1.13 & 2.134 & $0.914 \pm 0.002$ & $\mathrm{n} / \mathrm{a}$ & $58.4 \pm 7$ & $60.7 \pm 7$ \\
\hline $\mathrm{OH}-3$ & 1.29 & 2.585 & $0.91 \pm 0.016$ & 35.8 & $65 \pm 8$ & $67.9 \pm 8$ \\
\hline $\mathrm{OH}-4$ & 1.45 & 3.037 & $0.921 \pm 0.013$ & $\mathrm{n} / \mathrm{a}$ & $58.4 \pm 7$ & $61.8 \pm 7$ \\
\hline OH-5 & 1.61 & 3.579 & $0.932 \pm 0.002$ & 47.2 & $39.2 \pm 6$ & $43.1 \pm 6$ \\
\hline $\mathrm{OH}-6$ & 1.77 & 4.334 & $0.922 \pm 0.002$ & $\mathrm{n} / \mathrm{a}$ & $51.4 \pm 7$ & $56.2 \pm 7$ \\
\hline $\mathrm{OH}-7$ & 1.93 & 5.051 & $0.921 \pm 0.002$ & 38.1 & $52.3 \pm 8$ & $57.9 \pm 8$ \\
\hline $\mathrm{OH}-8$ & 2.09 & 5.977 & $0.922 \pm 0.002$ & $\mathrm{n} / \mathrm{a}$ & $50.4 \pm 7$ & $57 \pm 7$ \\
\hline OH-9 & 2.25 & 6.852 & $0.907 \pm 0.002$ & 43.6 & $52.4 \pm 7$ & $60.1 \pm 7$ \\
\hline $\mathrm{OH}-10$ & 2.41 & 7.704 & $0.899 \pm 0.002$ & $\mathrm{n} / \mathrm{a}$ & $60.2 \pm 7$ & $69 \pm 7$ \\
\hline $\mathrm{OH}-11$ & 2.57 & 8.318 & $0.898 \pm 0.003$ & 45.4 & $54 \pm 6$ & $63.4 \pm 6$ \\
\hline $\mathrm{OH}-12$ & 2.73 & 8.572 & $0.967 \pm 0.008$ & $\mathrm{n} / \mathrm{a}$ & $23.9 \pm 7$ & $32.8 \pm 7$ \\
\hline $\mathrm{OH}-13$ & 2.89 & 9.190 & $0.949 \pm 0.002$ & 41.1 & $33.4 \pm 7$ & $43.2 \pm 7$ \\
\hline $\mathrm{OH}-14$ & 3.05 & 10.130 & $0.984 \pm 0.003$ & $\mathrm{n} / \mathrm{a}$ & $18.8 \pm 7$ & $29.2 \pm 7$ \\
\hline $\mathrm{OH}-15$ & 3.21 & 11.111 & $0.961 \pm 0.003$ & 36.6 & $29.8 \pm 8$ & $41.4 \pm 8$ \\
\hline $\mathrm{OH}-16$ & 3.35 & 11.706 & $0.941 \pm 0.003$ & $\mathrm{n} / \mathrm{a}$ & $36.6 \pm 7$ & $49.2 \pm 7$ \\
\hline $\mathrm{OH}-17$ & 3.49 & 11.961 & $0.945 \pm 0.002$ & 37.5 & $36.6 \pm 8$ & $49.4 \pm 8$ \\
\hline $\mathrm{OH}-18$ & 3.65 & 12.232 & $0.936 \pm 0.002$ & $\mathrm{n} / \mathrm{a}$ & $38.5 \pm 7$ & $51.8 \pm 7$ \\
\hline OH-19 & 3.81 & 12.508 & $0.93 \pm 0.002$ & 36.3 & $47.5 \pm 8$ & $61.4 \pm 8$ \\
\hline $\mathrm{OH}-20$ & 3.97 & 12.778 & $0.922 \pm 0.003$ & $\mathrm{n} / \mathrm{a}$ & $45.1 \pm 7$ & $59.3 \pm 7$ \\
\hline $\mathrm{OH}-21$ & 4.13 & 13.070 & $0.960 \pm 0.002$ & 38.0 & $29.2 \pm 7$ & $43 \pm 7$ \\
\hline $\mathrm{OH}-22$ & 4.29 & 13.415 & $0.943 \pm 0.003$ & $\mathrm{n} / \mathrm{a}$ & $33.5 \pm 7$ & $48 \pm 7$ \\
\hline $\mathrm{OH}-23$ & 4.47 & 13.811 & $0.942 \pm 0.002$ & $\mathrm{n} / \mathrm{a}$ & $33.9 \pm 7$ & $48.8 \pm 7$ \\
\hline $\mathrm{OH}-24$ & 4.63 & 14.161 & $0.945 \pm 0.002$ & $\mathrm{n} / \mathrm{a}$ & $30.8 \pm 7$ & $46 \pm 7$ \\
\hline $\mathrm{OH}-25$ & 4.79 & 14.509 & $0.935 \pm 0.002$ & 39.1 & $38.2+8-7$ & $54.1+8-7$ \\
\hline $\mathrm{OH}-26$ & 4.95 & 14.859 & $0.926 \pm 0.002$ & $\mathrm{n} / \mathrm{a}$ & $40.5 \pm 7$ & $56.9 \pm 7$ \\
\hline $\mathrm{OH}-27$ & 5.11 & 15.217 & $0.937 \pm 0.002$ & 35.2 & $40.2 \pm 8$ & $56.9 \pm 8$ \\
\hline $\mathrm{OH}-28$ & 5.27 & 15.575 & $0.923 \pm 0.003$ & $\mathrm{n} / \mathrm{a}$ & $41.7 \pm 7$ & $58.9 \pm 7$ \\
\hline $\mathrm{OH}-29$ & 5.43 & 15.916 & $0.928 \pm 0.002$ & 33.1 & $49.4 \pm 9$ & $67.2 \pm 9$ \\
\hline
\end{tabular}


Albert, P. G., Hardiman, M., Keller, J., Tomlinson, E. L., Smith, V. C., Bourne, A. J., Wulf, S., Zanchetta, G., Sulpizio, R., Müller, U. C., Pross, J., Ottolini, L., Matthews, I. P., Blockley, S. P. E., and Menzies, M. A.: Revisiting the Y-3 tephrostratigraphic marker: a new diagnostic glass geochemistry, age estimate, and details on its climatostratigraphical context, Quaternary Science Reviews, 118, 105-121, 10.1016/j.quascirev.2014.04.002, 2015.

Aliaj, S., Baldassarre, G., and Shkupi, D.: Quaternary subsidence zones in Albania: some case studies, Bull Eng Geol Env, 59, $313-$ $318,10.1007 / \mathrm{s} 100640000063,2001$.

Aufgebauer, A., Panagiotopoulos, K., Wagner, B., Schaebitz, F., Viehberg, F. A., Vogel, H., Zanchetta, G., Sulpizio, R., Leng, M. J., and Damaschke, M.: Climate and environmental change in the Balkans over the last 17 ka recorded in sediments from Lake Prespa (Albania/F.Y.R. of Macedonia/Greece), Quaternary International, 274, 122-135, 10.1016/j.quaint.2012.02.015, 2012.

Balbo, A. L., Andric, M., Rubinic, J., Moscariello, A., and Miracle, P. T.: Palaeoenvironmental and Archaeological Implications of a Sediment Core from Polje Čepić, Istria, Croatia, Geologia Croatica, 59, 109-124, 2006.

Belmecheri, S., Namiotko, T., Robert, C., von Grafenstein, U., and Danielopol, D. L.: Climate controlled ostracod preservation in Lake Ohrid (Albania, Macedonia), Palaeogeography, Palaeoclimatology, Palaeoecology, 277, 236-245, 10.1016/j.palaeo.2009.04.013, 2009.

Blaauw, M. and Christen, J. A.: Flexible paleoclimate age-depth models using an autoregressive gamma process, Bayesian Analy sis, 6, 457-474, 10.1214/ba/1339616472, 2011.

Boek, E. S., Coveney, P. V., and Skipper, N. T.: Monte Carlo Molecular Modeling Studies of Hydrated Li-, Na-, and K-Smectites: Understanding the Role of Potassium as a Clay Swelling Inhibitor, Journal of the American Chemical Society, 117, 12608-12617, 10.1021/ja00155a025, 1995.

Bordon, A., Peyron, O., Lézine, A.-M., Brewer, S., and Fouache, E.: Pollen-inferred Late-Glacial and Holocene climate in southern Balkans (Lake Maliq), Quaternary International, 200, 19-30, 10.1016/j.quaint.2008.05.014, 2009.

Bourdon, B., Bureau, S., Andersen, M. B., Pili, E., and Hubert, A.: Weathering rates from top to bottom in a carbonate environment, Chemical Geology, 258, 275-287, 10.1016/j.chemgeo.2008.10.026, 2009.

Broecker, W. S.: Does atmospheric CO2 police the rate of chemical weathering?, Global Biogeochemical Cycles, 12, 403-408, doi:10.1029/98GB01927, 1998.

Cerdà, A.: Soil aggregate stability under different Mediterranean vegetation types, CATENA, 32, 73-86, 10.1016/S03418162(98)00041-1, 1998

Chabaux, F., Bourdon, B., and Riotte, J.: Chapter 3 U-Series Geochemistry in Weathering Profiles, River Waters and Lakes, in: Radioactivity in the Environment, edited by: Krishnaswami, S., and Cochran, J. K., Elsevier, 49-104, 2008.

Cogez, A., Meynadier, L., Allègre, C., Limmois, D., Herman, F., and Gaillardet, J.: Constraints on the role of tectonic and climate on erosion revealed by two time series analysis of marine cores around New Zealand, Earth and Planetary Science Letters, 410 , 174-185, 10.1016/j.epsl.2014.11.029, 2015.

Cohen, A. S.: Paleolimnology: The History and Evolution of Lake Sy stems, Oxford University Press, New York, 2003.

Combourieu-Nebout, N., Peyron, O., Bout-Roumazeilles, V., Goring, S., Dormoy, I., Joannin, S., Sadori, L., Siani, G., and Magny, M.: Holocene vegetation and climate changes in the central Mediterranean inferred from a high-resolution marine pollen record (Adriatic Sea), Clim. Past, 9, 2023-2042, 10.5194/cp-9-2023-2013, 2013.

Cvetkoska, A., Levkov, Z., Reed, J. M., and Wagner, B.: Late Glacial to Holocene climate change and human impact in the Mediterranean: The last ca. 17ka diatom record of Lake Prespa (Macedonia/Albania/Greece), Palaeogeography, Palaeoclimatology, Palaeoecology, 406, 22-32, 10.1016/j.palaeo.2014.04.010, 2014.

Damaschke, M., Sulpizio, R., Zanchetta, G., Wagner, B., Böhm, A., Nowaczyk, N., Rethemeyer, J., and Hilgers, A.: Tephrostratigraphic studies on a sediment core from Lake Prespa in the Balkans, Clim. Past, 9, 267-287, 10.5194/cp-9-267-2013, 2013.

DePaolo, D. J., Maher, K., Christensen, J. N., and McManus, J.: Sediment transport time measured with U-series isotopes: Results from ODP North Atlantic drift site 984, Earth and Planetary Science Letters, 248, 394-410, 10.1016/j.eps1.2006.06.004, 2006.

DePaolo, D. J., Lee, V. E., Christensen, J. N., and Maher, K.: Uranium comminution ages: Sediment transp ort and deposition time scales, Comptes Rendus Geoscience, 344, 678-687, 10.1016/j.crte.2012.10.014, 2012.

Digerfeldt, G., Sandgren, P., and Olsson, S.: Reconstruction of Holocene lake-level changes in Lake Xinias, central Greece, The Holocene, 17, 361-367, 10.1177/0959683607076449, 2007.

Dosseto, A., Turner, S., and Douglas, G.: Uranium-series isotopes in colloids and suspended sediments: Timescale for sediment production and transport in the Murray-Darling River system, Earth and Planetary Science Letters, 246, 418-431, 10.1016/j.epsl.2006.04.019, 2006.

Dosseto, A., Bourdon, B., and Turner, S. P.: Uranium-series isotopes in river materials: Insights into the timescales of erosion and sediment transport, Earth and Planetary Science Letters, 265, 1-17, 10.1016/j.eps1.2007.10.023, 2008a.

Dosseto, A., Turner, S. P., and Chappell, J.: The evolution of weathering profiles through time: New insights from uranium-series isotopes, Earth and Planetary Science Letters, 274, 359-371, 10.1016/j.epsl.2008.07.050, 2008b.

Dosseto, A. and Schaller, M.: The erosion response to Quaternary climate change quantified using uranium isotopes and in situproduced cosmogenic nuclides, Earth-Science Reviews, 155, 60-81, 10.1016/j.earscirev.2016.01.015, 2016.

Dreibrodt, S., Lubos, C., Hofmann, R., MÜLler-ScheeßEl, N., Richling, I., Nelle, O., Fuchs, M., Rassmann, K., KujundŽIĆVejzagiĆ, Z., Bork, H. R., and MÜLler, J.: Holocene river and slope activity in the Visoko Basin, Bosnia-Herzegovina - climate and land-use effects, Journal of Quaternary Science, 28, 559-570, 10.1002/jqs.2646, 2013.

Fouache, E., Dufaure, J.-J., Denèfle, M., Lézine, A.-M., Léra, P., Prendi, F., and Touchais, G.: Man and environment around lake Maliq (southern Albania) during the Late Holocene, Vegetation History and Archaeobotany, 10, 79-86, 10.1007/p100006922, 2001. Fouache, E., Desruelles, S., Magny, M., Bordon, A., Oberweiler, C., Coussot, C., Touchais, G., Lera, P., Lézine, A.-M., Fadin, L., and Roger, R.: Palaeogeographical reconstructions of Lake Maliq (Korça Basin, Albania) between 14,000 BP and 2000 BP, Journal of Archaeological Science, 37, 525-535, 10.1016/j.jas.2009.10.017, 2010.

Francke, A., Wagner, B., Leng, M. J., and Rethemeyer, J.: A Late Glacial to Holocene record of environmental change from Lake Dojran (Macedonia, Greece), Clim. Past, 9, 481-498, 10.5194/cp-9-481-2013, 2013.

Francke, A., Wagner, B., Just, J., Leicher, N., Gromig, R., B aumgarten, H., Vogel, H., Lacey, J. H., Sadori, L., Wonik, T., Leng, M. J., Zanchetta, G., Sulpizio, R., and Giaccio, B.: Sedimentological processes and environmental variability at Lake Ohrid (Macedonia, Albania) between $637 \mathrm{ka}$ and the present, Biogeosciences, 13, 1179-1196, 10.5194/bg-13-1179-2016, 2016. 
marine sediments, Chemical Geology, 479, 123-135, 10.1016/j.chemgeo.2018.01.003, 2018.

Gaillardet, J., Dupré, B., Louvat, P., and Allègre, C. J.: Global silicate weathering and CO2 consumption rates deduced from the chemistry of large rivers, Chemical Geology, 159, 3-30, 10.1016/S0009-2541(99)00031-5, 1999.

Gontier, A., Rihs, S., Chabaux, F., Lemarchand, D., Pelt, E., and Turpault, M.-P.: Lack of bedrock grain size influence on the soil production rate, Geochimica et Cosmochimica Acta, 166, 146-164, 10.1016/j.gca.2015.06.010, 2015.

Granet, M., Chabaux, F., Stille, P., France-Lanord, C., and Pelt, E.: Time-scales of sedimentary transfer and weathering processes from U-series nuclides: Clues from the Himalayan rivers, Earth and Planetary Science Letters, 261, 389-406, 10.1016/j.epsl.2007.07.012, 2007.

Granet, M., Chabaux, F., Stille, P., Dosseto, A., France-Lanord, C., and Blaes, E.: U-series disequilibria in suspended river sediments and implication for sediment transfer time in alluvial plains: The case of the Himalayan rivers, Geochimica et Cosmochimica Acta, 74, 2851-2865, 10.1016/j.gca.2010.02.016, 2010.

Gromig, R., Mechernich, S., Ribolini, A., Wagner, B., Zanchetta, G., Isola, I., Bini, M., and Dunai, T. J.: Evidence for a Younger Dryas deglaciation in the Galicica Mountains (FYROM) from cosmogenic 36Cl, Quaternary International, 464, 352-363, 10.1016/j.quaint.2017.07.013, 2018.

Handley, H. K., Turner, S., Afonso, J. C., Dosseto, A., and Cohen, T.: Sediment residence times constrained by uranium-series isotopes: A critical appraisal of the comminution approach, Geochimica et Cosmochimica Acta, 103, 245-262, 10.1016/j.gca.2012.10.047, 2013.

Hoffmann, N., Reicherter, K., Fernández-Steeger, T., and Grützner, C.: Evolution of ancient Lake Ohrid: a tectonic perspective, Biogeosciences, 7, 3377-3386, 10.5194/bg-7-3377-2010, 2010.

Hollis, G. E. and Stevenson, A. C.: The physical basis of the Lake Mikri Prespa systems: geology, climate, hydrology and water quality, in: Lake Prespa, Northwestern Greece: A Unique Balkan Wetland, edited by: Crivelli, A. J., and Catsadorakis, G., Springer Netherlands, Dordrecht, 1-19, 1997.

Holtvoeth, J., Vogel, H., Wagner, B., and Wolff, G. A.: Lipid biomarkers in Holocene and glacial sediments from ancient Lake Ohrid (Macedonia, Albania), Biogeosciences, 7, 3473-3489, 10.5194/bg-7-3473-2010, 2010.

Holtvoeth, J., Rushworth, D., Imeri, A., Cara, M., Vogel, H., Wagner, T., and Wolff, G. A.: Improved end-member characterization of modern organic matter pools in the Ohrid Basin (Albania, Macedonia) and evaluation of new palaeoenvironmental proxies, Biogeosciences Discuss., 12, 12975-13039, 10.5194/bgd-12-12975-2015, 2015.

Holtvoeth, J., Vogel, H., Valsecchi, V., Lindhorst, K., Schouten, S., Wagner, B., and Wolff, G. A.: Linear and non-linear responses of vegetation and soils to glacial-interglacial climate change in a Mediterranean refuge, Sci Rep, 7, 8121, 10.1038/s41598-01708101-y, 2017.

Ishikawa, M. and Ichikuni, M.: Uptake of sodium and potassium by calcite, Chemical Geology, 42, 137-146, 10.1016/00092541(84)90010-X, 1984.

Kigoshi, K.: Alpha-Recoil Thorium-234: Dissolution into Water and the Uranium-234/Uranium-238 Disequilibrium in Nature, Science, 173, 47, 1971.

Kosmas, C., Danalatos, N., Cammeraat, L. H., Chabart, M., Diamantopoulos, J., Farand, R., Gutierrez, L., Jacob, A., Marques, H., Martinez-Fernandez, J., Mizara, A., Moustakas, N., Nicolau, J. M., Oliveros, C., Pinna, G., Puddu, R., Puigdefabregas, J., Roxo, M., Simao, A., Stamou, G., Tomasi, N., Usai, D., and Vacca, A.: The effect of land use on runoff and soil erosion rates under Mediterranean conditions, CATENA, 29, 45-59, 10.1016/S0341-8162(96)00062-8, 1997.

Kouli, K.: Plant landscape and land use at the Neolithic lake settlement of Dispilió (Macedonia, northern Greece), Plant Biosystems - An International Journal Dealing with all Aspects of Plant Biology, 149, 195-204, 10.1080/11263504.2014.992998, 2015.

Lacey, J. H., Francke, A., Leng, M. J., Vane, C. H., and Wagner, B.: A high-resolution Late Glacial to Holocene record of environmental change in the Mediterranean from Lake Ohrid (Macedonia/Albania), International Journal of Earth Sciences, 104, 1623-1638, 10.1007/s00531-014-1033-6, 2015.

Lacey, J. H., Leng, M. J., Francke, A., Sloane, H. J., Milodowski, A., Vogel, H., Baumgarten, H., Zanchetta, G., and Wagner, B.: Northern Mediterranean climate since the Middle Pleistocene: a 637 ka stable isotope record from Lake Ohrid (Albania/Macedonia), Biogeosciences, 13, 1801-1820, 10.5194/bg-13-1801-2016, 2016.

Lee, V. E., DePaolo, D. J., and Christensen, J. N.: Uranium-series comminution ages of continental sediments: Case study of a Pleistocene alluvial fan, Earth and Planetary Science Letters, 296, 244-254, 10.1016/j.eps1.2010.05.005, 2010.

Leicher, N., Zanchetta, G., Sulpizio, R., Giaccio, B., Wagner, B., Nomade, S., Francke, A., and Del Carlo, P.: First tephrostratigraphic results of the DEEP site record from Lake Ohrid (Macedonia and Albania), Biogeosciences, 13, 2151-2178, 10.5194/bg-13-2151-2016, 2016.

Leng, M. J., Baneschi, I., Zanchetta, G., Jex, C. N., Wagner, B., and Vogel, H.: Late Quaternary palaeoenvironmental reconstruction from Lakes Ohrid and Prespa (Macedonia/Albania border) using stable isotopes, Biogeosciences, 7, 3109-3122, 10.5194/bg-7-3109-2010, 2010.

Lespez, L.: Geomorphic responses to long-term land use changes in Eastern Macedonia (Greece), CATENA, 51, 181-208, 10.1016/S0341-8162(02)00164-9, 2003.

Lézine, A. M., von Grafenstein, U., Andersen, N., Belmecheri, S., Bordon, A., Caron, B., Cazet, J. P., Erlenkeuser, H., Fouache, E., Grenier, C., Huntsman-Mapila, P., Hureau-Mazaudier, D., Manelli, D., Mazaud, A., Robert, C., Sulpizio, R., Tiercelin, J. J., Zanchetta, G., and Zeqollari, Z.: Lake Ohrid, Albania, provides an exceptional multi-proxy record of environmental changes during the last glacial-interglacial cycle, Palaeogeography, Palaeoclimatology, Palaeoecology, 287, 116-127, 10.1016/j.palaeo.2010.01.016, 2010.

Lindhorst, K., Vogel, H., Krastel, S., Wagner, B., Hilgers, A., Zander, A., Schwenk, T., Wessels, M., and Daut, G.: Stratigraphic analysis of lake level fluctuations in Lake Ohrid: an integration of high resolution hydro-acoustic data and sediment cores, Biogeosciences, 7, 3531-3548, 10.5194/bg-7-3531-2010, 2010.

Lindhorst, K., Krastel, S., Reicherter, K., Stipp, M., Wagner, B., and Schwenk, T.: Sedimentary and tectonic evolution of Lake Ohrid (Macedonia/Albania), Basin Research, 27, 84-101, 10.1111/bre.12063, 2015.

Luo, S., Ku, T.-L., Roback, R., Murrell, M., and McLing, T. L.: In-situ radionuclide transport and preferential groundwater flows at INEEL (Idaho): decay-series disequilibrium studies, Geochimica et Cosmochimica Acta, 64, 867-881, 10.1016/S00167037(99)00373-7, 2000.

Ma, L., Chabaux, F., Pelt, E., Blaes, E., Jin, L., and Brantley, S.: Regolith production rates calculated with uranium-series isotopes at Susquehanna/Shale Hills Critical Zone Observatory, Earth and Planetary Science Letters, 297, 211-225, 10.1016/j.eps1.2010.06.022, 2010. 
Geochimica et Cosmochimica Acta, 70, 4417-4435, 10.1016/j.gca.2006.06.1559, 2006.

Marston, R. A.: Geomorphology and vegetation on hillslopes: Interactions, dependencies, and feedback loops, Geomorphology, 116, 206-217, 10.1016/j.geomorph.2009.09.028, 2010.

Masi, A., Francke, A., Pepe, C., Thienemann, M., Wagner, B., and Sadori, L.: Vegetation history and paleoclimate at Lake Dojran (FYROM/Greece) during the Late Glacial and Holocene, Climate of the Past, 14, 351-367, 10.5194/cp-14-351-2018, 2018.

Matzinger, A., Spirkovski, Z., Patceva, S., and Wüest, A.: Sensitivity of Ancient Lake Ohrid to Local Anthropogenic Impacts and Global Warming, Journal of Great Lakes Research, 32, 158-179, 10.3394/0380-1330(2006)32[158:SOALOT]2.0.CO;2, 2006.

Matzinger, A., Schmid, M., Veljanoska-Sarafiloska, E., Patceva, S., Guseska, D., Wagner, B., Müller, B., Sturm, M., and Wüest, A.: Eutrophication of ancient Lake Ohrid: Global warming amplifies detrimental effects of increased nutrient inputs, Limnology and Oceanography, 52, 338-353, 2007.

Mercuri, A. M., Bandini Mazzanti, M., Florenzano, A., Montecchi, M. C., and Rattighieri, E.: Olea, Juglans and Castanea: The OJC group as pollen evidence of the development of human-induced environments in the Italian peninsula, Quaternary International, 303, 24-42, 10.1016/j.quaint.2013.01.005, 2013.

Ostberg, S., Boysen, L. R., Schaphoff, S., Lucht, W., and Gerten, D.: The Biosphere Under Potential Paris Outcomes, Earth's Future, 10.1002/2017ef000628, 2018.

Pal, Y., Gilkes, R. J., and Wong, M. T. F.: The forms of potassium and potassium adsorption in some virgin soils from southwestern Australia, Soil Research, 37, 695-710, 10.1071/SR98083, 1999.

Panagiotopoulos, K., Aufgebauer, A., Schäbitz, F., and Wagner, B.: Vegetation and climate history of the Lake Prespa region since the Lateglacial, Quaternary International, 292, 157-169, 10.1016/j.quaint.2012.05.048, 2013.

Panagiotopoulos, K., Böhm, A., Leng, M. J., Wagner, B., and Schäbitz, F.: Climate variability over the last 92 ka in SW Balkans from analy sis of sediments from Lake Prespa, Climate of the Past, 10, 643-660, 10.5194/cp-10-643-2014, 2014.

Popovska, C. and Stavric, V.: Transboundary river and lake basins in the Republic of Macedonia, 2004.

Rasmussen, S. O., Bigler, M., Blockley, S. P., Blunier, T., Buchardt, S. L., Clausen, H. B., Cvijanovic, I., Dahl-Jensen, D., Johnsen, S. J., Fischer, H., Gkinis, V., Guillevic, M., Hoek, W. Z., Lowe, J. J., Pedro, J. B., Popp, T., Seierstad, I. K., Steffensen, J. P., Svensson, A. M., Vallelonga, P., Vinther, B. M., Walker, M. J. C., Wheatley, J. J., and Winstrup, M.: A stratigraphic framework for abrupt climatic changes during the Last Glacial period based on three synchronized Greenland ice-core records: refining and extending the INTIMATE event stratigraphy, Quaternary Science Reviews, 106, 14-28, 10.1016/j.quascirev.2014.09.007, 2014.

Ribolini, A., Isola, I., Zanchetta, G., Bini, M., and Sulpizio, R.: Glacial feature on the Galicica Mountains, Macedonia: preliminary report, Geogr. Fis. Dinam. Quat., 34, 247-255, 10.4461/GFDQ.2011.34.22, 2011.

Rothacker, L., Dosseto, A., Francke, A., Chivas, A. R., Vigier, N., Kotarba-Morley, A. M., and Menozzi, D.: Impact of climate change and human activity on soil landscapes over the past 12,300 years, Scientific Reports, 8, 10.1038/s41598-017-18603-4, 2018. Sadori, L., Koutsodendris, A., Panagiotopoulos, K., Masi, A., Bertini, A., Combourieu-Nebout, N., Francke, A., Kouli, K., Joannin, S., Mercuri, A. M., Peyron, O., Torri, P., Wagner, B., Zanchetta, G., Sinopoli, G., and Donders, T. H.: Pollen-based paleoenvironmental and paleoclimatic change at Lake Ohrid (south-eastern Europe) during the past 500 ka, Biogeosciences, 13, 1423-1437, 10.5194/bg-13-1423-2016, 2016.

Siani, G., Sulpizio, R., Paterne, M., and Sbrana, A.: Tephrostratigraphy study for the last 18,000 C-14 years in a deep-sea sediment sequence for the South Adriatic, Quaternary Science Reviews, 23, 2485-2500, 10.1016/j.quascirev.2004.06.004, 2004.

Styllas, M. N., Schimmelpfennig, I., Benedetti, L., Ghilardi, M., Aumaître, G., Bourlès, D., and Keddadouche, K.: Late-glacial and Holocene history of the northeast Mediterranean mountain glaciers - New insights from in situ -produced $36 \mathrm{Cl}$ - based cosmic ray exposure dating of paleo-glacier deposits on Mount Olympus, Greece, Quaternary Science Reviews, 193, 244-265, 10.1016/j.quascirev.2018.06.020, 2018.

Sulpizio, R., Zanchetta, G., D'Orazio, M., Vogel, H., and Wagner, B.: Tephrostratigraphy and tephrochronology of lakes Ohrid and Prespa, Balkans, Biogeosciences, 7, 3273-3288, 10.5194/bg-7-3273-2010, 2010.

Suresh, P. O., Dosseto, A., Hesse, P. P., and Handley, H. K.: Soil formation rates determined from Uranium-series isotope disequilibria in soil profiles from the southeastern Australian highlands, Earth and Planetary Science Letters, 379, 26-37, 10.1016/j.eps1.2013.08.004, 2013.

Suresh, P. O., Dosseto, A., Handley, H. K., and Hesse, P. P.: Assessment of a sequential phase extraction procedure for uraniumseries isotope analy sis of soils and sediments, Appl Radiat Isot, $83 \mathrm{Pt} \mathrm{A,} \mathrm{47-55,} \mathrm{10.1016/j.apradiso.2013.10.013,} \mathrm{2014a.}$

Suresh, P. O., Dosseto, A., Hesse, P. P., and Handley, H. K.: Very long hillslope transport timescales determined from uraniumseries isotopes in river sediments from a large, tectonically stable catchment, Geochimica et Cosmochimica Acta, 142, 442-457, 10.1016/j.gca.2014.07.033, 2014b.

Thienemann, M., Masi, A., Kusch, S., Sadori, L., John, S., Francke, A., Wagner, B., and Rethemeyer, J.: Organic geochemical and palynological evidence for Holocene natural and anthropogenic environmental change at Lake Dojran (Macedonia/Greece), The Holocene, 1-12, 10.1177/0959683616683261, 2017.

Vogel, H., Wagner, B., Zanchetta, G., Sulpizio, R., and Rosén, P.: A paleoclimate record with tephrochronological age control for the last glacial-interglacial cycle from Lake Ohrid, Albania and Macedonia, Journal of Paleolimnology, 44, 295-310, 10.1007/s 10933-009-9404-x, 2010a.

Vogel, H., Wessels, M., Albrecht, C., Stich, H. B., and Wagner, B.: Spatial variability of recent sedimentation in Lake Ohrid (Albania/Macedonia), Biogeosciences, 7, 3333-3342, 10.5194/bg-7-3333-2010, 2010b.

Vogel, H., Zanchetta, G., Sulpizio, R., Wagner, B., and Nowaczyk, N.: A tephrostratigraphic record for the last glacial-interglacial cycle from Lake Ohrid, Albania and Macedonia, Journal of Quaternary Science, 25, 320-338, 10.1002/jqs.1311, 2010c.

Vött, A., Brückner, H., Zander, A. M., May, S. M., Mariolakos, I., Lang, F., Fountoulis, I., and Dunkel, A.: Late Quaternary evolution of Mediterranean poljes - the Vatos case study (Akarnania, NW Greece) based on geo-scientific core analy ses and IRSL dating, Zeitschrift für Geomorphologie, 53, 145-169, 10.1127/0372-8854/2009/0053-0145, 2009.

Wagner, B., Sulpizio, R., Zanchetta, G., Wulf, S., Wessels, M., Daut, G., and Nowaczyk, N.: The last 40 ka tephrostratigraphic record of Lake Ohrid, Albania and Macedonia: a very distal archive for ash dispersal from Italian volcanoes, Journal of Volcanology and Geothermal Research, 177, 71-80, 10.1016/j.jvolgeores.2007.08.018, 2008.

Wagner, B., Lotter, A. F., Nowaczyk, N., Reed, J. M., Schwalb, A., Sulpizio, R., Valsecchi, V., Wessels, M., and Zanchetta, G.: A 40,000-year record of environmental change from ancient Lake Ohrid (Albania and Macedonia), Journal of Paleolimnology, 41, 407-430, 10.1007/s10933-008-9234-2, 2009.

Wagner, B., Vogel, H., Zanchetta, G., and Sulpizio, R.: Environmental change within the Balkan region during the past ca. $50 \mathrm{ka}$ recorded in the sediments from lakes Prespa and Ohrid, Biogeosciences, 7, 3187-3198, 10.5194/bg-7-3187-2010, 2010. 
Lushaj, B., and Trajanovski, S.: Possible earthquake trigger for 6th century mass wasting deposit at Lake Ohrid (Macedonia/Albania), Clim. Past, 8, 2069-2078, 10.5194/cp-8-2069-2012, 2012.

Wagner, B., Wilke, T., Krastel, S., Zanchetta, G., Sulpizio, R., Reicherter, K., Leng, M. J., Grazhdani, A., Trajanovski, S., Francke, A., Lindhorst, K., Levkov, Z., Cvetkoska, A., Reed, J. M., Zhang, X., Lacey, J. H., Wonik, T., Baumgarten, H., and Vogel, H.: The SCOPSCO drilling project recovers more than 1.2 million years of history from Lake Ohrid, Sci. Dril., 17, 19-29, 10.5194/sd-1719-2014, 2014

Watzin, M., Puka, V., and Naumoski, T.: Lake Ohrid and its Watershed. State of the Environment Report. Lake Ohrid Conservation Project, Tirana, Albania and Ohrid, Macedonia, 2002.

Zanchetta, G., Sulpizio, R., Roberts, N., Cioni, R., Eastwood, W. J., Siani, G., Caron, B. Æ., Paterne, M., and Santacroce, R.: Tephrostratigraphy, chronology and climatic events of the Mediterranean basin during the Holocene: An overview, The Holocene, 21, 33-52, 10.1177/0959683610377531, 2011.

Zanchetta, G., Baneschi, I., Francke, A., Boschi, C., Regattieri, E., Wagner, B., Lacey, J. H., Leng, M. J., Vogel, H., and S adori, L.: Evidence for carbon cycling in a large freshwater lake in the Balkans over the last 0.5 million years using the isotopic composition of bulk organic matter, Quaternary Science Reviews, 202, 154-165, 10.1016/j.quascirev.2018.10.022, 2018. 
- Soil systems evolution on geological time scales since the Late Glacial

- "Paleo sediment residence times" and soil erosion on the Balkan Peninsula

- Innovative trace metal (uranium) isotope analyses

- Quantifying soil systems evolution in the light of climate change and land use

- Threshold response in soil systemevolution 


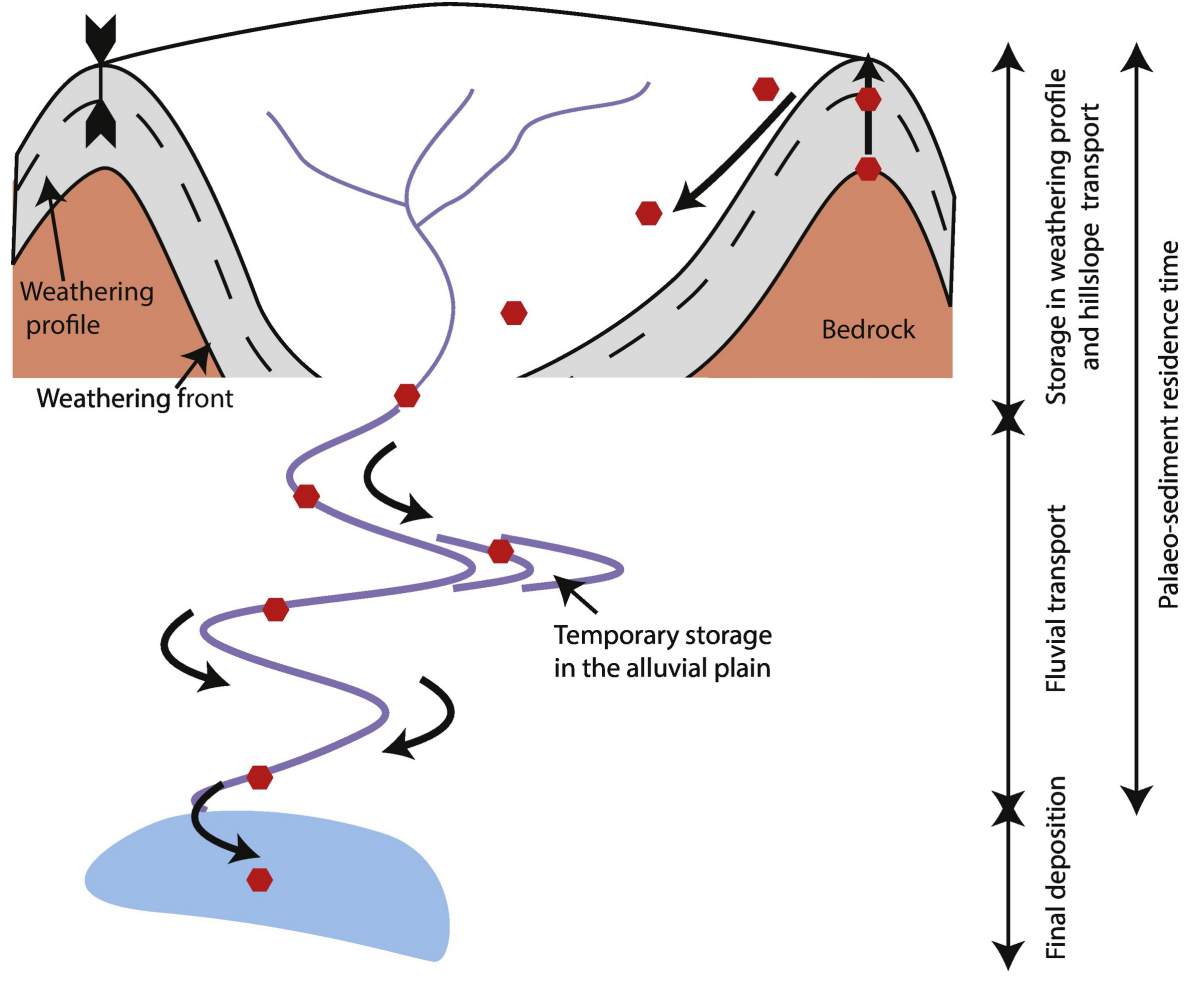

Figure 1 


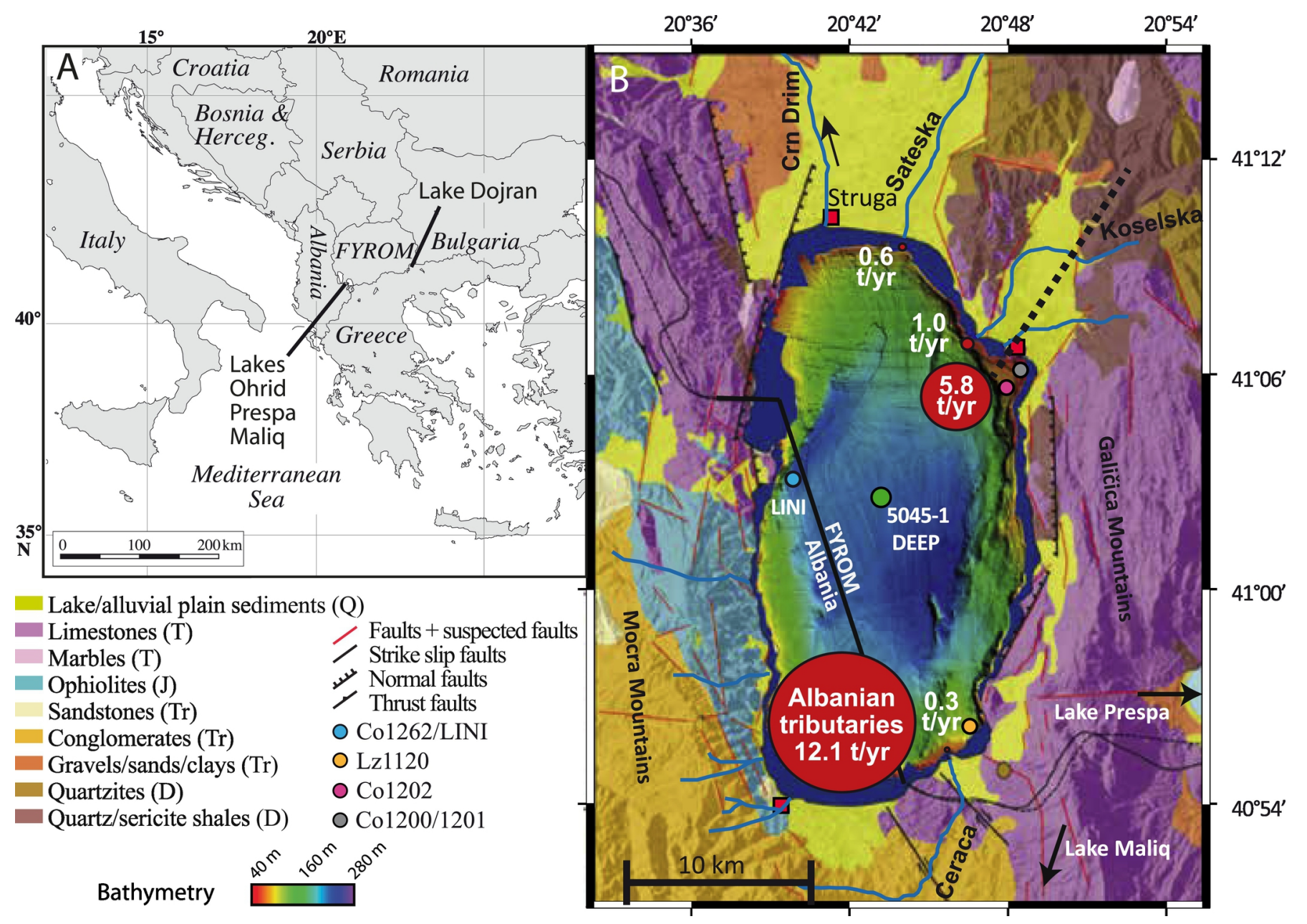

Figure 2 

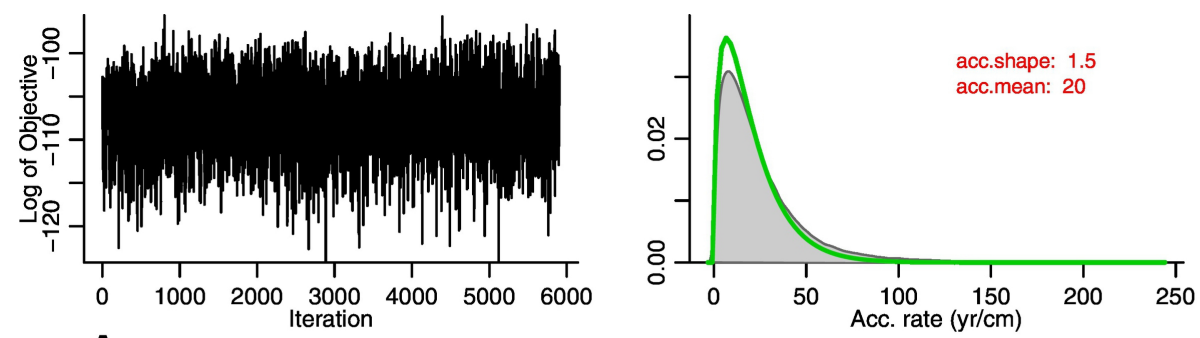

A

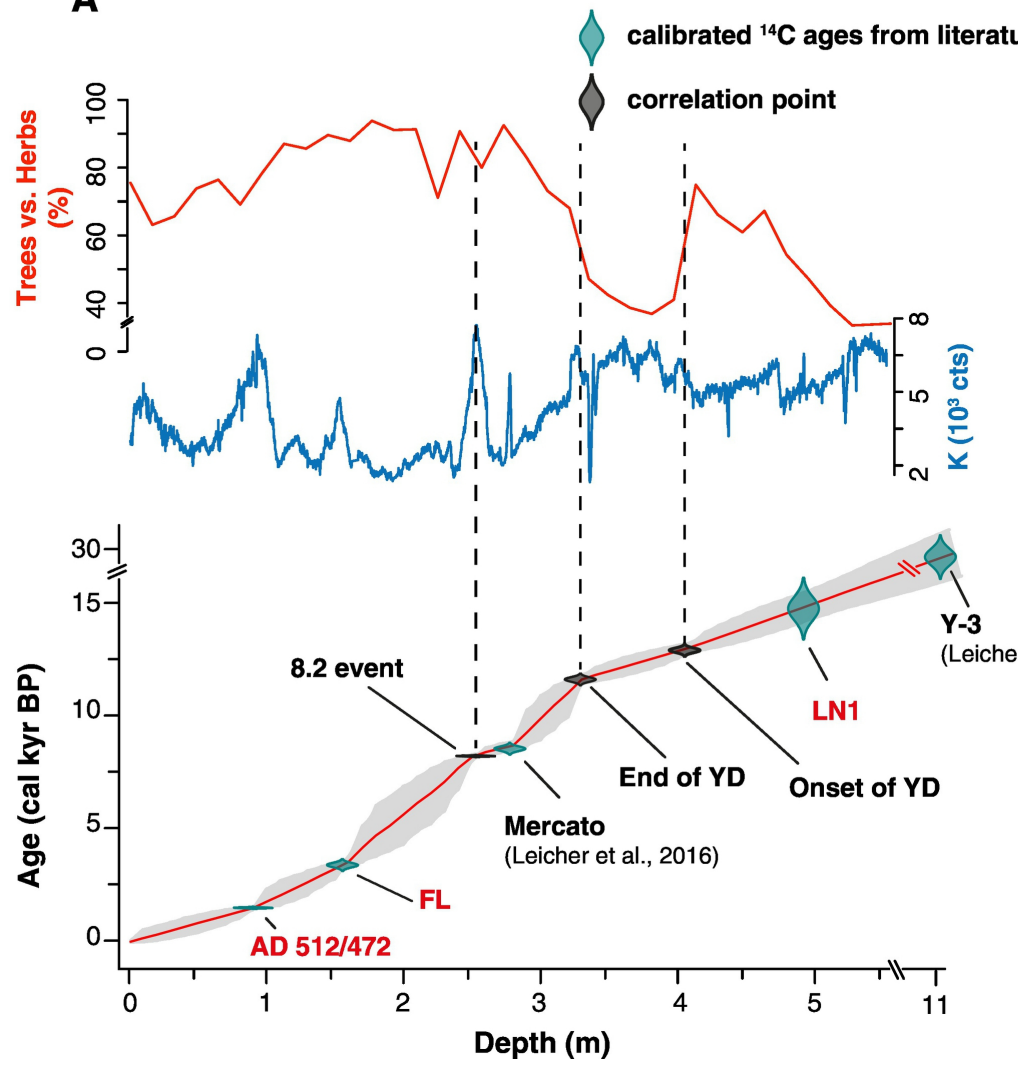

B

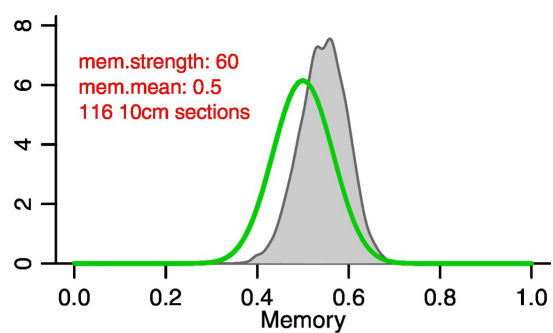

\section{Comparision Ohrid vs Prespa}
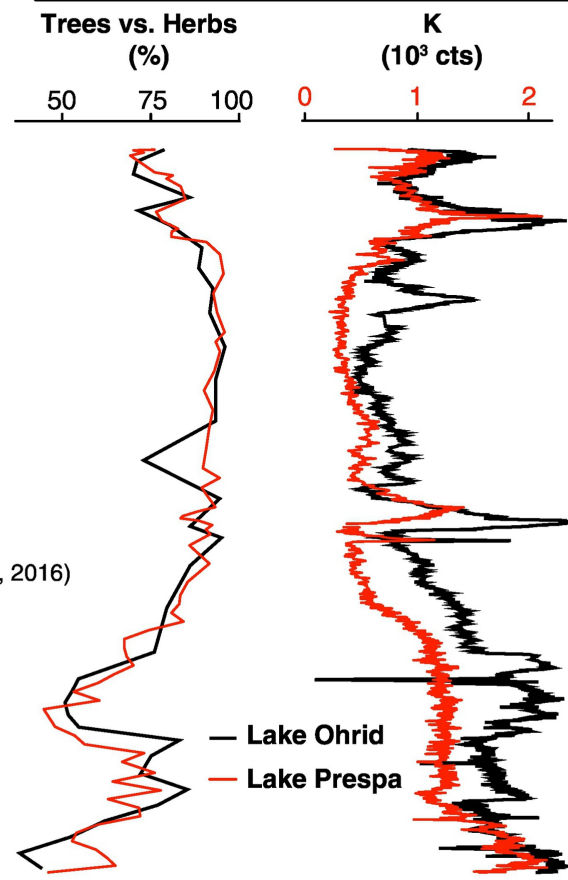

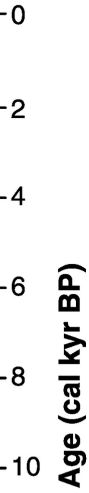

- Lake Ohrid

- Lake Prespa -14

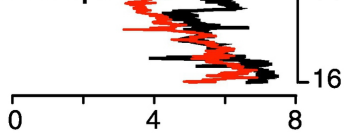




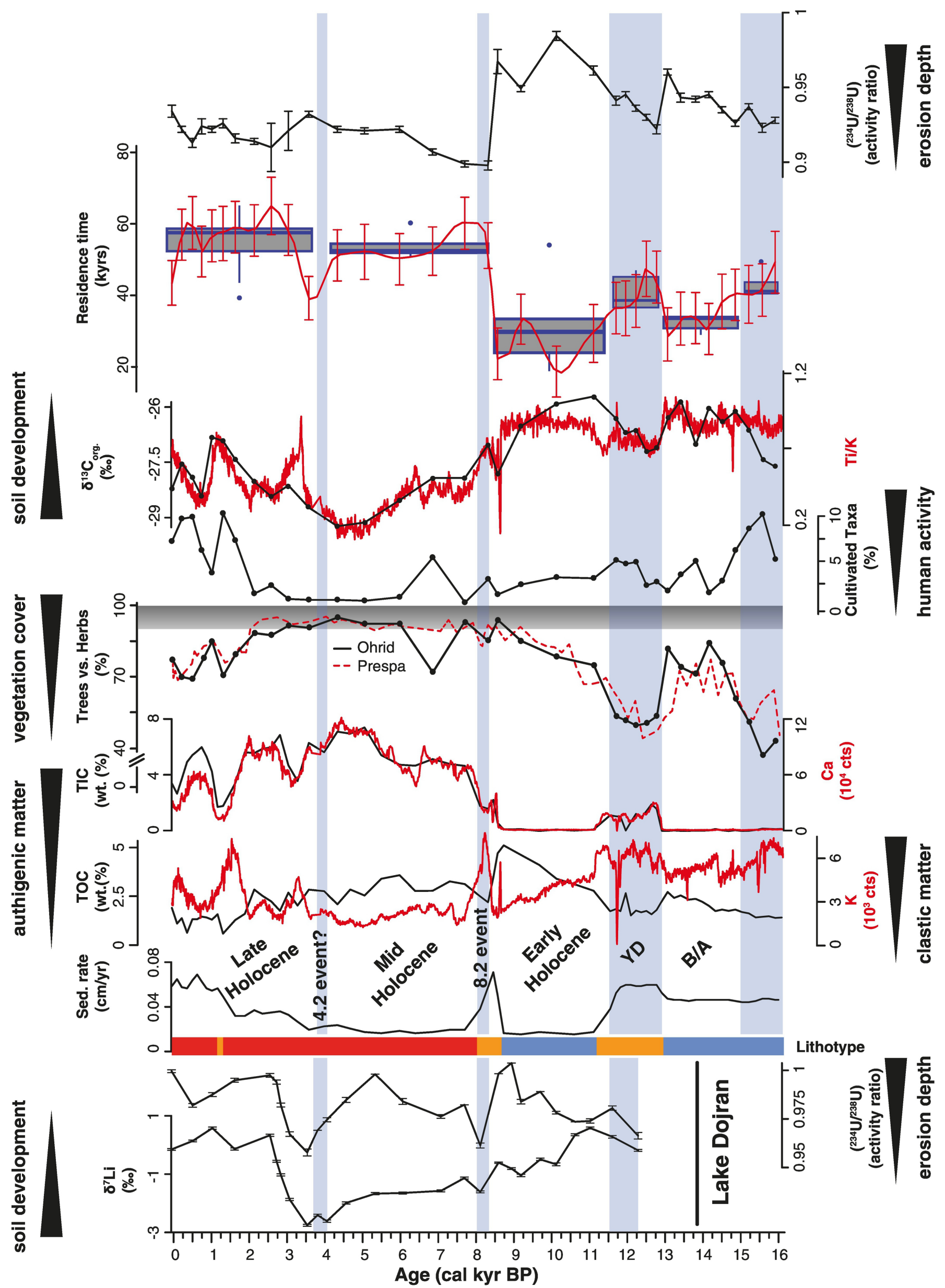

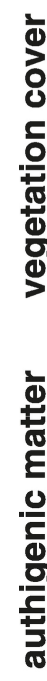

ò

$\square$ Lithotype 1: calcareous silty clay $\square$ Lithotype 2: sligthly calcareous silty clay $\square$ Lithotype 3: silty clay 


\section{Late Glacial / Early Holocene}

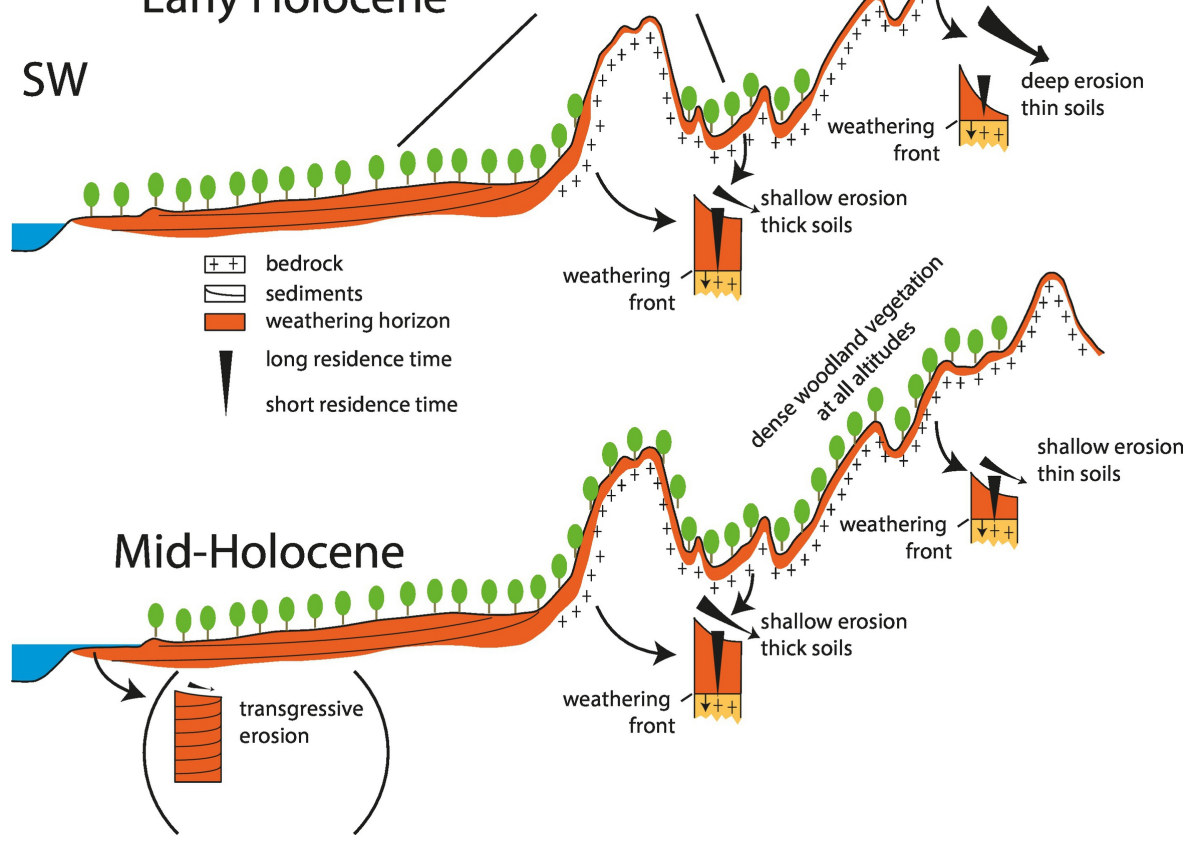

Figure 5 